\title{
Algunas lecturas francesas de las independencias hispanoamericanas*
}

Recibido: 08/02/2018 | Revisado: 02/04/2019 | Aceptado: 08/05/2019 DOI: 10.17230/co-herencia.16.31.4

\author{
Juan Camilo Escobar Villegas** \\ jcescoba@eafit.edu.co
}

\author{
Adolfo León Maya Salazar ${ }^{* * *}$ \\ amayasa@eafit.edu.co
}

Resumen En este artículo, se analiza la documentación pro ducida por autores franceses o afrancesados, en la cual América y sus procesos de independencia, en particular los hispanoamericanos, ocupan un lugar central. Se localiza un importante corpus documental que incluye libros e impresos periódicos. Algunos de ellos fueron de uso en las escuelas primarias y secundarias francesas, otros circularon entre académicos y profesores universitarios. También se analizan algunos textos provenientes de conmemoraciones americanistas, como discursos de legatarios o personalidades con prestigio político o científico, y textos literarios que concursaron en variados eventos vinculados con las celebraciones y conmemoraciones de la Independencia. A partir de ellos, se proponen cinco ejes de reflexión: primero, desde la perspectiva de las representaciones sociales, políticas y culturales de las independencias hispanoamericanas, donde las preocupaciones investigativas están orientadas a lo que se dice que pasó y menos a lo que pasó. Segundo, la reiteración de la categoría influencia para pensar las relaciones decimonónicas entre América y Francia subraya la originalidad de las ideas ilustradas y la Revolución Francesa; en cambio, las revoluciones hispanoamericanas representarían una de sus consecuencias más o menos distorsionada a este lado del Atlántico. Tercero, el lenguaje hermenéutico de lo que se dice que pasó instituyó mitos políticos modernos, asociados directamente con una revolución exitosa, igualitaria, libertaria y fraterna. Cuarto, en el contexto planetario de las dinámicas de modernización política, "lo francés" debe ser pensado como una parte de los procesos de mundialización de la modernidad. Quinto, el examen social y cultural de la producción intelectual presentada permite una mirada crítica a las historias nacionales (Francia, Colombia, España, México, etc.) o continentales (Europa, América, Latinoamérica, etc.), de tal forma que se puedan comprender mejor los procesos de modernización.
* Este artículo se realiza en el marco del proyecto de investigación "Representaciones sociales, políticas y culturales de las independencias iberoamericanas", que hace parte del grupo de investigación Sociedad, Política e Historias Conectadas, del Departamento de Gobierno y Ciencias Políticas, Escuela de Humanidades, Universidad EAFIT.

** Doctor en Historia y Civilizaciones, Escuela de Altos Estudios en Ciencias Sociales (EHESS). Profesor del Departamento de Gobierno y Ciencias Políticas de la Universidad EAFIT, Medellín, Colombia. ORCID: 0000. 0001-8264-5571

**** Magíster en Ciencias Políticas de la Universidad de Antioquia. Profesor del Departamento de Gobierno y Ciencias Políticas de la Universidad EAFIT, Medellín, Colombia. ORCID: 0000-00024758-4846 


\section{Palabras clave:}

Procesos de independencia, Revolución Francesa, ideas ilustradas, Hispanoamérica, representaciones mentales, historiografía francesa, afrancesados, historia intelectual.

\section{Some French readings of the Spanish- American independence processes}

Abstract This paper analyzes documents produced by French or Frenchified authors, in which America and its independence processes, particularly SpanishAmerican processes, occupy center stage. An important documentary corpus was found including books and periodicals. Some of these materials were used in French primary and secondary schools, others circulated among scholars and university professors. Some texts from Americanist acts of commemoration are also analyzed, such as speeches by legatees or personalities with political or scientific prestige, as well as literary texts that competed in a variety of events related to Independence celebrations and acts of commemorations. Based on these documents, five lines of reflection are proposed. First, from the perspective of social, political and cultural representations of Spanish-American independence processes, the research interest is focused more on what is said to have happened and less on what actually happened. Second, the reiteration of the category of influence to approach the nineteenth-century relations between America and France highlights the originality of the Enlightenment ideas and the French Revolution; by contrast, the Spanish-American revolutions would represent one of its consequences, more or less distorted on this side of the Atlantic. Third, the hermeneutic language of what is said to have happened created modern political myths, directly linked with a successful, egalitarian, libertarian and fraternal revolution. Fourth, in the world context of political modernization dynamics, "the French" should be construed as a part of modernity globalization processes. Fifth, the social and cultural examination of the intellectual production considered here sheds a critical light on national (France, Colombia, Spain, Mexico, etc.) or continental (Europe, America, Latin America, etc.) histories, which allows modernization-related processes to be better understood.

\section{Keywords:}

Independences processes, French Revolution, enlightened ideas, Spanish America, mental representations, French historiography, Frenchified, intellectual history. 
Las lecturas francesas de las independencias hispanoamericanas no son un caso excepcional. Los pronunciamientos galos hacen parte de un gran abanico de consideraciones efectuadas sobre América en todos los continentes, desde el siglo XIX hasta la actualidad. Los grupos de estudios bolivarianos y americanistas han surgido a través del mundo para celebrar los acontecimientos y las vidas de los llamados héroes de las revoluciones y procesos independistas a lo largo del continente americano, o para inspirar otros movimientos sociales y políticos en los demás espacios continentales del planeta. De acuerdo con la documentación recopilada, es posible decir que los procesos independentistas americanos no han sido indiferentes para la gran mayoría de los proyectos de modernización en el mundo. Bolívar disputa, con Robespierre, Washington, Napoleón, Martí y otros, los lugares de honor en la memoria política moderna.

Los documentos compilados por Alberto Filippi (1995), en los tres volúmenes sobre Europa y Bolívar, indican ya una enorme pluralidad de pronunciamientos sobre las independencias hispanoamericanas. En esta importante publicación de fuentes primarias, Filippi recopila textos provenientes de España, Francia, Italia, Alemania, Gran Bretaña, Dinamarca, Holanda, Suecia, Suiza, Polonia, Rusia, Hungría, Checoslovaquia, Portugal y Rumania. Textos que invitan, de inmediato, a pensar en historias conectadas, en relación con la construcción de diversas representaciones sociales, políticas y culturales de las independencias hispanoamericanas, por parte de una comunidad intercontinental de intelectuales y personalidades de Estado que, cercanos a los intereses geopolíticos de esos países, producen una serie de memorias, gramáticas y narrativas que funcionan como legitimaciones de diversos proyectos modernos y antimodernos de sociedad y poder. El lenguaje conmemorativo sirve para ello. Los discursos de embajadores, las obras de artistas y escritores, así como las manifestaciones sociales de simpatizantes o no de lo moderno, coadyuvan a la proliferación y circulación de imágenes materiales e inmateriales de América en el mundo.

En medio de ese arsenal de narraciones e historias, América, en ocasiones pensada como el continente en su totalidad, ha incentivado, desde el siglo XIX, la creación de una dinámica historiográfica, de carácter mundial, que ha producido gran cantidad de obras sobre 
los procesos independentistas, en particular durante las dos primeras décadas del siglo XXI. Revisando algunos de los clásicos de esa historiografía y tratando de acercarse a lo que podría ser el estado del arte del objeto de estudio no se han hallado, hasta ahora, estudios que se refieran a los autores citados a lo largo de este artículo. Excepto algunas referencias a Alexis de Tocqueville, obras de gran impacto historiográfico como las de François Chevalier y FrançoisXavier Guerra no se detienen en autores como Alfred Deberle, Paul Guerin, Georges Aubert, José María Torres-Caicedo, François Bianconi, Manuel María Buenaventura, José Manuel Groot o Gabriel Hanotaux, quienes sustentan, entre otros, las reflexiones que aquí se plantean en torno a una notable vertiente entre las distintas lecturas mundiales sobre las independencias hispanoamericanas: la francesa, durante la segunda mitad del siglo XIX y el primer tercio del siglo XX. ${ }^{1}$

Puede decirse, empero, que las sociabilidades científicas, literarias y políticas fueron una estrategia para la consolidación de ideas y acciones, en las cuales América se fue convirtiendo en un protagonista de primera línea en la geopolítica mundial. De acuerdo con el fundador y director del Comité France-Amérique (1920), Gabriel Hanotaux, "el hecho capital de la vida internacional del siglo XIx ha sido probablemente la liberación de las colonias españolas y portuguesas del Nuevo Mundo y la constitución de las veinte repúblicas de América Latina" (p. 1).

El continente americano, todavía nuevo para muchos ojos europeos, fue motivando, después de las luchas de independencia, la creación de diversas agrupaciones intelectuales, comerciales y diplomáticas, así como sociedades literarias y científicas que lograron mantenerse activas durante varias décadas. La importancia cultural, política y económica de estos grupos de euroamericanos se resaltaba en variadas publicaciones, logrando atraer nuevos miembros y produciendo una serie de representaciones mentales sobre los pasados

1 Se han revisado, en particular, las obras de François Chevalier (1999) y de FrançoisXavier Guerra (2001). Además, entre las publicaciones en torno al bicentenario de las independencias hispanoamericanas, se revisaron trabajos como los de Manuel Lucena Giraldo (2010), María Teresa Calderón y Clément Thibaut (2010), Yobenj Aucardo Chicangana-Bayona y Francisco Alberto Ortega Martínez (2011), Francisco A. Ortega y Yobenj Aucardo Chicangana-Bayona (2011). En ellos tampoco se encontraron referencias al objeto de estudio. 
de ambos continentes. Los convenios logrados entre gobernantes, intelectuales y diplomáticos posibilitaban, a su vez, acceso a recursos públicos y privados, publicaciones de nuevos textos en forma de libros, revistas, periódicos, boletines u otros formatos, así como la realización de eventos conmemorativos, renombrando calles, plazas y lugares con rótulos americanos y europeos, enviando embajadores y delegados por ambos continentes, y elaborando planes estratégicos de política internacional muy propia tanto de los imperios como del pensamiento neocolonizador de los siglos XIX y XX en Europa. Con ello, se lograba, simultáneamente, occidentalizar y americanizar la geopolítica planetaria.

Para efectos de este texto, se ha puesto la atención en la documentación producida por autores franceses o afrancesados, en la cual América y sus procesos de independencia, en particular los hispanoamericanos, ocupan un lugar central. Se ha localizado un importante corpus documental que incluye libros e impresos periódicos; algunos fueron utilizados en las escuelas primarias y secundarias francesas, otros circularon entre académicos y profesores universitarios. Igualmente, se ubicaron algunos textos provenientes de conmemoraciones americanistas, como discursos de legatarios o personalidades con prestigio político o científico, y escritos literarios que concursaron en variados eventos vinculados con las celebraciones y conmemoraciones de la Independencia, como los juegos florales (Escobar Villegas y Maya Salazar, 2010). Queda pendiente una revisión más detallada en archivos públicos y privados, donde deben existir numerosos manuscritos o documentos inéditos que fueron producidos y leídos por funcionarios o intelectuales durante sus trabajos.

Es importante anotar que el acervo documental primario presentado en este texto se encuentra en la Biblioteca Nacional de Colombia. No obstante, es necesario agregar que la mayoría de esas fuentes también constituyen activos patrimoniales de otras bibliotecas americanas, incluida la Library of Congress de Estados Unidos. Numerosas publicaciones de Gabriel Hanotaux y de Francois Bianconi, por ejemplo, se encuentran en los anaqueles de estos lugares de memoria del mundo. El texto de Alfred Deberle, Histoire de l'Amérique du Sud, depuis la conquête jusqu'à nos jours, publicado en 1876, en París, se encuentra en la Biblioteca del Congreso de 
los Estados Unidos traducida al español y al inglés. Allí se puede leer una edición publicada en Barcelona, en 1878, y siete ediciones norteamericanas, entre 1899 y 1939. Las obras de los afrancesados neogranadinos que se mencionan en los apartados siguientes también hacen parte de las travesías que realizaron los textos franceses revisados y pensados en este artículo. José María Samper, Jose Manuel Restrepo y José María Quijano Otero, en particular, tuvieron eco con sus libros en los territorios hispanoamericanos. Para constatarlo, basta revisar la gran mayoría los catálogos de las bibliotecas nacionales de América.

A partir de la documentación revisada, se propone una reflexión sobre algunas lecturas francesas de las independencias hispanoamericanas. Para ello, se presentan cinco apartados denominados de la siguiente manera: 1) las ideas ilustradas francesas como causa principal de las rupturas políticas del continente americano con la península ibérica; 2) la Revolución Francesa como el modelo de la modernidad social, política y cultural del mundo hispanoamericano; 3) el papel del afrancesamiento de ciertos miembros de las élites hispanoamericanas en la exaltación de Francia como el referente de civilización; 4) la subvaloración de la cultura hispana a favor de la latina, frontera construida por una serie de imaginarios de identidad que separaría lo francés de lo sajón, lo hispánico, lo germánico y otras "comunidades imaginadas" por los europeos durante el siglo XIX; 5) la consecuente legitimación de las múltiples y variadas formas del neocolonialismo francés en el contexto de la época de los imperialismos europeos en diversos continentes (siglos XIX y XX).

\section{Las ideas ilustradas como causa}

No es fácil separar las ideas ilustradas de las no ilustradas. La historiografía no tiene un acuerdo general sobre esta delimitación. Existen manuales que han propagado una visión según la cual el siglo XVIII es la época de las ideas ilustradas, el tiempo de la Ilustración o del Iluminismo, queriendo con ello facilitar la manipulación de la historia de las sociedades en compartimientos separados por fechas, por franjas temporales que se mitifican, levantan muros y crean ficciones sobre el tiempo histórico que no se corresponden con el azaroso mundo en el cual se mueven los actores sociales. La gente del 
siglo XVIII, como la de otros siglos, amalgamaba ideas de su tiempo y de otras temporalidades, produciendo, con frecuencia, resultados novedosos, pero no siempre radicalmente diferentes. Las ideas en general, sean ilustradas o no, cuando circulan lo hacen en cabeza de alguien, en manos de sujetos concretos que las reinventan, mezclan, interpretan y adaptan de manera sorpresiva.

Los letrados, los intelectuales que vivían en América durante los años de las revoluciones independentistas, o que se comunicaban desde Europa con los americanos, tuvieron a su disposición libros y espacios de discusión con los cuales formaron sus visiones del mundo y sus proyectos de vida social, política, económica y cultural. Muchos de esos textos y de esos lugares de la palabra, de las imágenes y los gestos eran creados por la acción de sus contemporáneos, así como por la presencia de sus antepasados, lo que permitiría pensar en una mecánica histórica que no funciona en la lógica clásica de causa-efecto, sino que actúa, más bien, como un caleidoscopio, en el cual un movimiento inesperado en cualquiera de las partes produce un panorama original, singular, que a la vez comparte tonalidades, intensidades y espesores con otros conjuntos cercanos o lejanos en el tiempo o el espacio. El historiador, como el niño que juega con el caleidoscopio, se convierte en un nuevo movimiento inesperado que recrea panoramas, ensambla acontecimientos, produce contextos y explica las complejas razones de las transformaciones y continuidades históricas.

Ahora bien, historiador no es solo quien ostenta el diploma universitario, es también el que logra organizar un discurso más o menos coherente y consigue difundirlo en algún medio que llega a oídos u ojos de otros, de tal forma que interviene el panorama del pasado. Las explicaciones dadas a los cambios ocurridos en América hispánica provienen de historiadores universitarios y aficionados; no obstante, sus textos no se diferencian siempre en los procesos de recepción y adaptación durante los usos sociales que se hace de ellos: usos educativos, en los sistemas escolares; políticos, en los proyectos de gobierno; ideológicos, por medio de la divulgación periodística y mediática contemporánea; y culturales, diluidos gracias a la sutil divulgación que de ellos se hace en los diferentes escenarios de la vida cotidiana, como las mesas de comedor, los salones de reuniones, las 
discusiones entre amigos, los teatros, cines, iglesias y demás lugares de sociabilidad que inventan las sociedades en su diario vivir.

Los documentos que aseguran una causalidad directa entre ideas ilustradas francesas y revoluciones de independencia en Hispanoamérica son, en efecto, muy variados, tanto como los que participan en la generación de los otros cuatro ejes que se analizan en este texto y que articulan algunas de las lecturas francesas de los sucesos acaecidos en las primeras décadas del siglo XIX, en las antiguas Indias Occidentales. El Diccionario de los diccionarios, publicado en París en 1895, asegura que Simón Bolívar, llamado el Liberador, "dotado de inteligencia y voluntad, aprendió las principales lenguas de la Europa, estudió en Madrid, y viajó por los dos mundos, donde se inició en las ideas de progreso y libertad. Al regresar a su patria, su primer acto fue liberar sus esclavos negros" (Guérin, 1895, p. 101). Ideas que liberan gente esclavizada, podría decirse. Ideas de Europa, de Madrid y de los dos mundos, de Francia, Italia, España e Inglaterra, ideas ilustradas de acuerdo con los atributos que se le otorgan en los manuales escolares al llamado también Iluminismo.

No obstante, es necesario preguntar, para no perder de vista las complejas resistencias culturales y políticas a los ideales abolicionistas que, desde el siglo XVII, empezaron a circular por el planeta, si las ideas ilustradas, en particular las francesas, fueron tan generosas y tan libertarias, ipor qué entonces fueron tan lentos y difíciles los procesos políticos y sociales para lograr la liberación definitiva de la gente esclavizada a lo largo del siglo XIX, en tantos territorios del mundo donde los europeos ilustrados fueron protagonistas de primer orden? ${ }^{2}$

Volviendo al Diccionario de los diccionarios, es importante notar que su director, Paul Guérin, era un hombre de iglesia, un prelado de la Diócesis de Langres del parlamento de Haute-Marne, en Francia; quien, a su vez, también figuraba como "protonotario apostólico" y profesor de filosofía en diversas instituciones francesas, entre ellas el College de Saint Dizier, en la misma región de Francia. ${ }^{3}$ Así, esta obra de carácter monumental se presenta como una "Enciclopedia

2 Para acercarse a este tema, pueden verse los textos y las polémicas que se escribieron a raíz de la publicación del libro Le Code noir ou le calvaire de Canaan, escrito por Louis Sala-Molins (1987).

3 Información disponible en el catálogo de la Biblioteca Nacional de Francia. 
universal de letras, ciencias y artes", siguiendo una tradición intelectual propia de los proyectos ilustrados, que pretendían sistematizar, ordenar y recopilar todo el conocimiento existente, tal como lo habían intentado ilustrados ingleses, franceses, alemanes, españoles, entre otros, en el siglo XVIII. El ejemplo más conocido, quizás por la exitosa política de difusión de la llamada "civilización francesa", es la Enciclopedia o Diccionario razonado de las ciencias, de las artes y de los oficios, que inició su publicación en 1751, bajo la dirección de Denis Diderot.

La obra dirigida por el prelado y profesor Paul Guérin estaba en la misma línea con sus siete volúmenes. Ella pretendía recopilar y ordenar los conocimientos humanos que posibilitaba el entendimiento de los hombres, como lo había publicado Diderot. En esa totalidad deseada, aparecían ahora los acontecimientos y sujetos americanos, como Simón Bolívar y sus luchas por independizar los territorios hispanoamericanos. En las palabras del Diccionario de Guérin, Bolívar se debe principalmente a sus viajes por los mundos, en los cuales "las ideas de progreso y libertad" existen. Ideas que el Libertador pudo asimilar gracias a las dotes de "inteligencia y voluntad" que la naturaleza le ha otorgado y a las lenguas aprendidas en Europa.

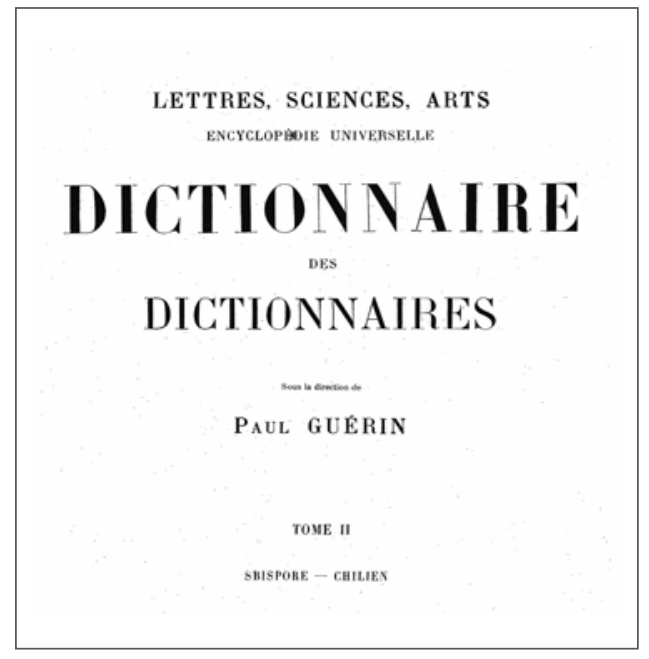

Imagen 1. Portada de Dictionnaire des dictionnaires: encyclopédie universelle des lettres, des sciences et des arts (Guérin, 1895).

Fuente: Biblioteca Nacional de Colombia 
Por su parte, François Bianconi, un ingeniero jefe de los ferrocarriles otomanos, aseguraba que los "países de América del sur y central, países del futuro", son los territorios "en donde más se inspiran de las ideas francesas y donde el espíritu francés domina" (Bianconi y Broc, 1887, p. 5). Sus palabras se encuentran en una colección de estudios generales geográficos, patrocinada por los ministerios de comercio, relaciones exteriores, instrucción pública, guerra, marina, agricultura y trabajos públicos. Además, contaba con el apoyo de la subsecretaría de Estado de las colonias, de la ciudad de París y de varias cámaras de comercio de Francia. Su publicación y circulación estaban garantizadas por las suscripciones de las anteriores entidades políticas y económicas. Los ejemplares de dicha colección llevaban por título la expresión: cartes commerciales, es decir, mapas comerciales; y, por subtítulo, las siguientes denominaciones y objetivos, con los cuales se definían los mapas: físicos, políticos, administrativos, viales, etnográficos, minerales y agrícolas.

Estos textos e imágenes provenientes de diversas partes del mundo proponían una amplia descripción apoyada en la colaboración de los principales viajeros franceses que normalmente regresaban a Europa para publicar sus observaciones y sus interpretaciones de las sociedades visitadas. En efecto, las Cartes commerciales de Bianconi se preocupaban por describir con detalle, a partir de "la información más reciente", "la historia de los hábitos, las costumbres, el número de pobladores, las estadísticas comerciales, los productos importables, la creación de nuevas industrias, la legislación, la administración, los tribunales, etc., etc" (Bianconi y Broc, 1887), como se indicaba en la portada del texto (ver Imagen 2). De acuerdo con lo dicho por este promotor de una economía política de carácter global, con epicentro en Francia y su orgullosa tradición ideológica y cultural, "todo concurrirá entonces al desarrollo de nuestro comercio" (Bianconi y Broc, 1887, p. 5). 


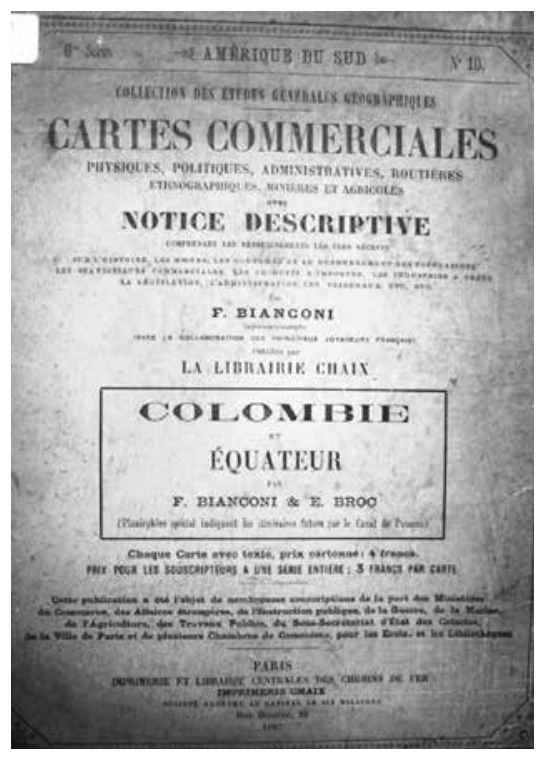

Imagen 2. Portada de Colombie et Équateur, Collection des études générales géographiques, Cartes commerciales (Bianconi y Broc, 1887).

Fuente: Biblioteca Nacional de Colombia

Es posible decir, siguiendo las palabras de Bianconi, que el "espíritu francés" que dominaba Hispanoamérica podría favorecer el desarrollo comercial francés. Pero ¿qué podría ser dicho espíritu? Quizás esté refiriéndose a la triada conceptual que adorna los edificios públicos en Francia, después de la revolución liberal de 1789, en la cual libertad, igualdad y fraternidad funcionaron como un atractivo constituido por atributos seductores que permitían explicar la historia de los otros. En este caso, las independencias hispanoamericanas parecieran obedecer a la narración que estos autores franceses del siglo XIX hicieron, primero, de sus propios procesos de cambio social y político; y luego, de los que fueron sucediendo en otras latitudes, porque tanto en aquellos como en estos se compartían lenguajes e ideales ilustrados que han favorecido la creación de repúblicas liberales en el mundo.

En otras palabras, se puede afirmar que las ideas ilustradas se mundializaron y permitieron diálogos interculturales por medio de ideales libertarios, igualitarios y solidarios, pero con orígenes no 
exclusivamente franceses, en tanto que las rutas ilustradas fueron multidireccionales. En efecto, sujetos ilustrados florecieron en diversas partes del mundo. Las ideas ilustradas no tuvieron patria, cruzaron las fronteras sin permisos aduaneros, sin consultas protocolarias. Por ello, es necesario evitar una perspectiva nacionalista o localista para pensar y comprender la compleja trama de la modernidad política y de los procesos de modernización que se llevaron a cabo, imbricándose y adaptándose de formas originales.

Las "ideas francesas" han sido una reiterativa explicación para entender las transformaciones políticas en muchas partes del mundo. Parece que ellas se han difundido por el planeta de manera natural, como si estuviesen destinadas a impactar las convicciones de quienes leen un autor ilustrado francés o de aquellos que se enteran de los acontecimientos filosóficos y políticos ocurridos en Francia. Dicha dinámica fue común en el siglo XIX, pero es posible decir que, en ocasiones, esta explicación causal ha trascendido más allá de los tiempos decimonónicos, tal y como se puede observar en algunos apartados de este texto. Por ejemplo, el recurso explicativo a las "ideas francesas" siguió siendo razón suficiente para que el escritor ruso, decano de la Facultad de Derecho y Ciencias Políticas de la Escuela Libre de Altos Estudios de Nueva York, Boris Mirkine-Guetzévitch (18921955), afirmara que "los eventos europeos apasionaron a esta élite criolla, y es bajo la influencia de las ideas francesas que esta activa minoría debía dar, un poco más tarde, la señal de revolución en América Latina" (Mirkine-Guetzévitch, 1936, p. 4).

Este intelectual, profesor también en el Instituto de Altos Estudios Internacionales de la Universidad de París, aseguraba que esta "influencia" había permitido que los revolucionarios hispanoamericanos pudieran pensar y desencadenar una ruptura con la Corona española. Mirkine-Guetzévitch, en 1936, redactó el prefacio a un número especial de los Cahiers de la Revolution Française, a cargo de Hugo D. Barbagelata. Dicha publicación hacía parte del Centre d'Études de la Revolution, de la Facultad de Letras de la Universidad de París, y fue dedicada a pensar las relaciones entre la Revolución Francesa y América Latina. Llama la atención la imagen de verticalidad que se desprende de la noción "influencia". Vector tajante, lineal y agudo que tiene en un extremo un influenciador creativo, 
fuerte, activo y poderoso; y, en el otro, un influenciado copiador, débil, pasivo y receptivo. En otros términos, la Revolución Francesa y sus ideas ilustradas fueron originales, auténticas, sin influencias, y las revoluciones de independencia de Hispanoamérica representaban una de sus consecuencias gloriosas, un efecto que había que explicar desde París.

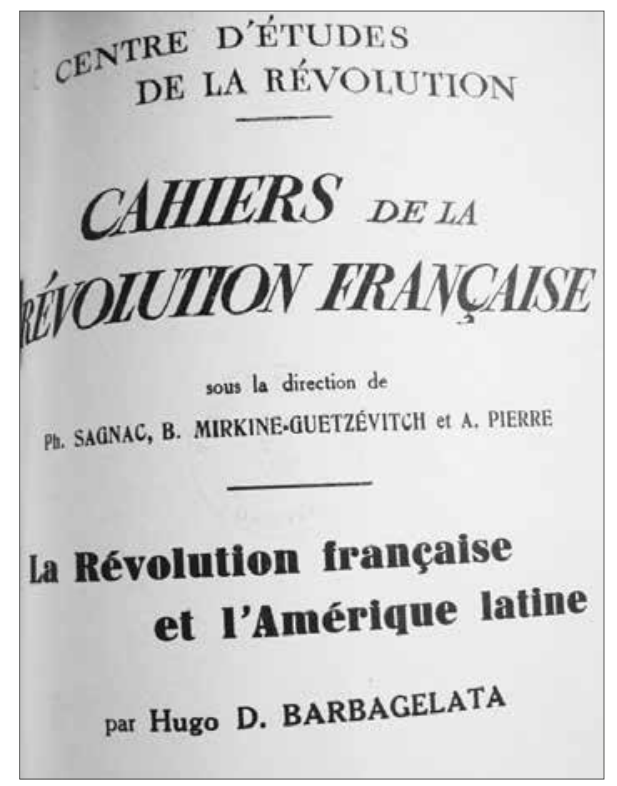

Imagen 3. Portadilla de Cahiers de la Révolution Française (Sagnac, Mirkine-Guetzévitch y Pierre, 1936).

Fotografía: Paola Galeano, Biblioteca Nacional de Francia

\section{La Revolución Francesa como modelo}

Tal como se desprende de las líneas anteriores, la Revolución Francesa se había convertido no solo en un acontecimiento político de finales del siglo XviII en Europa, sino que había logrado volverse un modelo, quizás el modelo político por excelencia, para explicar las luchas de independencia en América hispánica. Dicho arquetipo generó varios mitos políticos, entre ellos, el de una revolución plenamente exitosa porque había logrado poner fin a la Edad Media, al oscurantismo, al antiguo régimen, a los privilegios nobiliarios y 
clericales, y había hecho reales la libertad, la igualdad y la fraternidad. Parte de ese mito ha ocultado, con frecuencia, las desigualdades reales entre los franceses del siglo XIX y, por qué no decirlo, de los de hoy, en el paso del año 2018 al 2019, cuando los "chalecos amarillos" están mostrando las fracturas de la igualdad y la fraternidad entre las poblaciones de las periferias francesas y las privilegiadas de las grandes capitales.

Las promesas no cumplidas de la Revolución Francesa produjeron levantamientos populares en 1830 para volver a destronar las fuerzas monárquicas que se habían restaurado quince años atrás; motivaron nuevas revueltas populares en 1848 y 1871, para recordarle a las élites dirigentes de Francia que la revolución social estaba inconclusa; generaron, en mayo de 1968, huelgas obreras y protestas estudiantiles para cuestionar e interrogar otros poderes menos visibles, como la desigualdad de las mujeres y las discriminaciones raciales existentes en Francia como consecuencia de sus derivas coloniales en África y Asia.

Otro mito de la Revolución Francesa como modelo se revela en la idea de "un pueblo enérgico que se ha hecho libre por su propia voluntad" (Deberle, 1876, p. 90), tal como lo escribió el periodista y autor de libros de lectura para niños, en su Historia de América del sur, desde la conquista hasta nuestros días, Alfred Deberle (1835-1877), un año antes de morir (ver Imagen 4).

Ahora bien, entre las tradiciones interpretativas de la Revolución Francesa, también hay ciertos elementos que han cobrado carácter paradigmático incuestionable, como ha sido el caso del documento escrito en agosto de 1789 y conocido bajo el prestigioso título de Declaración de los derechos del hombre y del ciudadano. Texto político de gran valor en su contexto, pero también es posible decir que en él no estaban incluidas las mujeres, lo que impulsó a la osada escritora Olympe de Gouges a escribir, dos años después, la Declaración de los derechos de la mujer y de la ciudadana, en tiempos de guillotinas y tribunales revolucionarios que decapitaron a los adversarios sin posibilidades de defensa jurídica. Ante ese tribunal fue llevada De Gouges, siendo sentenciada a la pena capital. El 3 de noviembre de 1793 fue decapitada, pero dejaba tras de sí un nuevo Artículo 1.o en su Declaración: "La mujer nace libre y permanece igual al hombre 
en derechos. Las distinciones sociales sólo pueden estar fundadas en la utilidad común” (De Gouges, 1791, p. 7). Palabras que los líderes dominantes de la Revolución Francesa, a finales del siglo XVIII, encontraban incómodas y, en ocasiones, antinaturales (ver Imagen 5).

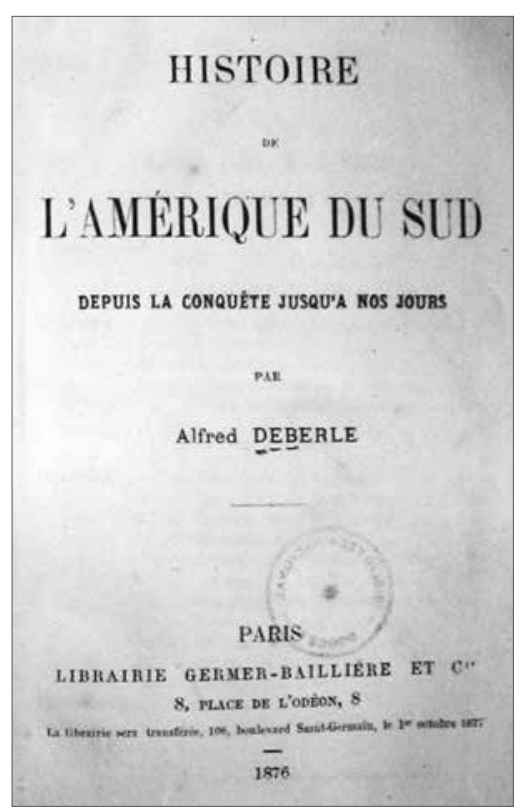

Imagen 5. Página interior del texto Déclaration des droits de la femme et de la citoyenne (De Gouges, 1791). Se encuentra precedido de un escrito titulado: "Los Derechos de la mujer.
Imagen 4. Portadilla de Histoire de l'Amérique du Sud, depuis la conquête jusqu'à nos jours (Deberle, 1876).

Fuente: Sala de Patrimonio Documental. Biblioteca Universidad EAFIT

\section{(6)}

lumières et de sagacité, dans lignorance la plus crasse, il vent commander en despote sur un sexe qui a reçu toutes les facultés intellectuelles; il prétend jouir de la révolution, et réclamer ses droits à l'égalité, pour ne rien dire de plus.

DÉCLARATION DES DROITS DE LA FEMME ET DE LA CITOYENNE,

1 decriter par l'Assemblé nationale dans ses dernières séances ou dans celle de la'prochaine législature.

$$
\text { P I E A B U I E. }
$$

Les mères, les filles, les soeurs, représentantes de la nation, demandent d'etre constituées en assemblée nationale. Considérant que l'ignorance, l'oubli ou le mépris des droits de la femme, sont les seules canses des malheurs publics et de la corruption des gouvernemens, ont résolu d'exposer dans une déclaration solemnelle, les droits naturels, inaliénables et sacrés de la femme, afin que cette déclantion, constamment présente à tous les membres du corps social, leur rappclle sans cesse leurs droits et leurs devoirs, afin que les actes du pouvoir des A la Reina". 
Igual suerte corrió otra activista política y escritora en esos tiempos turbulentos, revolucionarios y confusos, Marie-Jeanne Roland de la Platière o, simplemente, Madame Roland, quien fue también guillotinada ese mismo año. En el periódico Le Moniteur Universel, de 1793, se reimprimió lo que había sido publicado en la Feuille du salut public (Hoja de Seguridad Pública) por una "sociedad de gente de letras patriotas", grupo de varones defensores de la revolución y de la Declaración de los derechos del hombre y del ciudadano, y partidarios del nuevo sistema político republicano. En un tono de proclama, escribieron una razonada y elocuente justificación de la sentencia dada contra esta otra atrevida mujer. Aquí un fragmento de sus explicaciones y convicciones: "La señora Roland, de notable inteligencia y con grandes proyectos, es un monstruo en todos los sentidos, ha sacrificado la naturaleza al querer elevarse por encima de ella; el deseo de ser sabia, la condujo al olvido de las virtudes de su sexo" (Société de gens de lettres patriotes, 1793, como se citó en Godineau, 1995, p. 424).

La Declaración de los derechos del hombre y del ciudadano no es un documento único ni completamente original en Euroamérica. Dicho texto hace parte de la historia del individualismo y del liberalismo que venían gestándose en aquellos siglos modernos que tenían, en el siglo XVI, rupturas científicas y religiosas, así como reflexiones humanistas y renacentistas que fundamentaban consideraciones con las cuales los individuos podían ser y sentirse responsables de sí mismos. Copérnico, Galileo, Lutero, Erasmo, Da Vinci y otros científicos y reformadores sentaron bases importantes para que, en los siglos siguientes, se pudieran escribir textos que defendían derechos, como el contundente Bill of rights, en Inglaterra en 1689, que ponía límites al poder del rey y favorecía una renovada institución política, el parlamento o lugar de la palabra, en donde debían desarrollarse elecciones libres para escoger a sus miembros, y en el cual "la libertad de palabra y los debates o procedimientos en el Parlamento no deben ser acusados o cuestionados en ninguna Corte o lugar, fuera del Parlamento" (Parlamento Británico, 1689, p. 198).

En esta misma dirección, se puede situar la conocida Declaración de Independencia de Estados Unidos, cuyo título original es The unanimous declaration of the thirteen United States of America, oficializada 
por el Segundo Congreso Continental, el 4 de julio de 1776, en Filadelfia, como documento fundacional de un nuevo orden político al norte del continente americano. En su creación, estuvieron hombres ilustrados, individuos que compartían con muchos otros sujetos de Europa y América conjuntos de imágenes mentales sobre el poder público o imaginarios políticos, con los cuales llevaron a cabo revoluciones liberales que favorecían la creación y defensa de nuevos derechos individuales. Entre estos legisladores de los Estados Unidos, se encontraba Benjamin Franklin (1706-1790): lector, corresponsal y comentarista de la Ciencia de la legislación (1780-1789), obra del filósofo napolitano Gaetano Filangieri (1753-1788). Un ejemplo, entre muchos más de los contactos, conexiones, circulaciones y comunidades intelectuales que construían un lenguaje político común, promovían un cosmopolitismo moderno que no permite hoy asegurar que las formas de hacer, sentir y pensar lo político tuvieran una pertenencia exclusivamente nacional.

Las noticias de lo que pasaba en Europa y América circulaban a ambos lados del Atlántico. Demoraban algunas semanas atravesando el océano o algunos meses para llegar de una ciudad a otra, pero aquellas novedades eran recibidas con interés, en el contexto de ciertas mentalidades que ocasionaban tensiones, dejaban dudas, originaban esperanzas y permitían planear nuevas propuestas, gracias a las acciones de producción, difusión, recepción, apropiación y adaptación propias de los procesos de mundialización que han venido presentándose, sistemáticamente, desde el siglo XVI en muchos ámbitos de la vida humana.

En efecto, los ilustrados granadinos de finales del siglo XVIII hacían parte de los procesos de mundialización política que se sucedían con cierta rapidez entre Europa y América. Los conocidos hechos alrededor de la publicación de la Declaración de los derechos del hombre y del ciudadano, en Santafé de Bogotá, en 1794, cuando Antonio Nariño y varios de sus contemporáneos fueron juzgados o encarcelados en el marco de la llamada "revolución de los pasquines", muestran que los escritos de las revoluciones liberales euroamericanas circulaban, se leían y suscitaban nuevos escritos y representaciones sobre las formas políticas en pugna, en particular las monárquicas y las republicanas. 
Ahora bien, estas circulaciones multidireccionales no fueron percibidas por algunos de los escritores francesas que se pronunciaron, en el siglo XIX, sobre las luchas de independencia en Hispanoamérica. En ese sentido, se puede citar, de nuevo, a Alfred Deberle, para quien la Revolución Francesa y la Declaración de los derechos del hombre y del ciudadano transformaron íntegramente a Simón Bolívar, permitiendo que pasara de ser un joven desconocido sin responsabilidades ni límites, a figurar como un hombre libre, respetado y famoso. Deberle (1876) aseguraba que Bolívar era el mejor aliado de los franceses porque "sus meditaciones estuvieron tempranamente guiadas hacia Francia, hacia los principios de nuestra revolución inmortal, y de un hombre joven, irresponsable y libertino, la Declaración de los derechos del hombre ha hecho un ciudadano y un héroe" (p. 116). De esta forma, es posible decir que, con frecuencia, algunos de los esfuerzos intelectuales que hicieron ciertos escritores franceses generaron no solo parte de la mitología sobre la Revolución Francesa como el modelo político por excelencia de la modernidad, sino también una simplificación de las complejas condiciones en las cuales se produjeron las independencias en Hispanoamérica y se formaron, ideológica y políticamente, sus diversos actores sociales en múltiples lugares.

\section{El afrancesamiento de las élites hispanoamericanas}

La expresión "élites hispanoamericanas afrancesadas" debe entenderse de forma precisa en este texto; es decir, como un grupo social de poder cuyos miembros eran nacidos en América hispánica, pero quienes, además, tenían una fuerte simpatía con Francia. Entre las élites hispanoamericanas del siglo XIX hubo, en efecto, un enorme interés por los procesos históricos de Francia; sin embargo, es importante anotar que ese interés había tenido un notorio impulso durante el siglo XVIII, en el contexto de lo que ha sido conocido como las Reformas Borbónicas. Dichas reformas, promovidas por una corte de origen familiar francés, no solo ubicaron parientes borbones en las instituciones de la monarquía española, sino que permitieron la circulación de ideas, libros, gustos, costumbres, saberes y acontecimientos políticos que tenían gran fuerza en Francia. 
De esta manera, Felipe v (1683-1746), Fernando VI (1713-1759) y Carlos III (1716-1788), reyes de España, generaron con sus políticas de gobierno una expansión importante de los procesos de circulación euroamericanos. En medio de ellos, estuvieron acontecimientos como la publicación de numerosos textos, la creación de sociabilidades científicas, artísticas y literarias, la Independencia de Estados Unidos, las luchas de los comuneros, la Revolución Francesa, las sociedades económicas de amigos del país, la liberalización del comercio hispanoamericano, las traducciones de manifiestos políticos y una mayor movilidad de las élites hispanoamericanas por los espacios europeos. En este sentido, lo "francés" debe ser pensado como parte de unos procesos de mundialización multidireccionales, en los cuales participaban sujetos de diversos orígenes, entre ellos los afrancesados, quienes serían, a la vez, simpatizantes de Francia y de otras tradiciones culturales.

En esos contextos de finales del siglo XVIII y comienzos del XIX, las independencias hispanoamericanas estuvieron acompañadas por descontentos, malestares y desconfianzas entre estamentos sociales y políticos tanto en las colonias como en la administración monárquica. Los efectos de la reconquista económica que la Corona había emprendido en los territorios de sus dominios para asegurar el recaudo de nuevos y mayores impuestos con destino a la metrópoli estimularon protestas, insurrecciones, desobediencias y choques entre "pueblos que se les agotó la paciencia", según palabras de José María Quijano Otero (1883, p. 119), para aludir a comerciantes y pobladores de Simacota, Mongotes y Chalará que estaban sintiendo el rigor de las reformas borbónicas en el ámbito fiscal.

En otras palabras, lo que se había ido constituyendo en los ámbitos culturales de Europa y América - pero también del mundo- era una nueva comunidad intercontinental de formas de hacer, sentir y pensar las relaciones sociales y los órdenes políticos. Por otra parte, y para no entrar en los terrenos de una reflexión de carácter nacionalista, es menester precisar que, en esa comunidad, intelectuales y políticos nacidos en la Francia del siglo XVIII habían tenido una presencia importante, pero no exclusiva y determinante, como lo proponían con frecuencia los autores aquí presentados. Parece com- 
prensible el etnocentrismo de los franceses, como el de tantos otros pueblos del mundo, pero dicho conjunto de representaciones sobre lo que había ocurrido en las independencias hispanoamericanas se vio fortalecido, durante el siglo XIX y buena parte del XX, por el fuerte afrancesamiento de algunos escritores hispanoamericanos. El origen de dicho afrancesamiento apasionado, como se dijo antes, estuvo ligado a un numeroso intercambio de ideas y noticias, entre las cuales se encontraban las que los autores y diplomáticos franceses empezaron a promover para explicar por qué casi la totalidad de los territorios hispanoamericanos habían obtenido independencia política. Muy temprano, en la década de 1820, los gobiernos franceses y los ingleses estuvieron muy atentos a los resultados de los enfrentamientos militares entre España y sus dominios en América, con el fin de fijar sus posturas frente a los nuevos Estados.

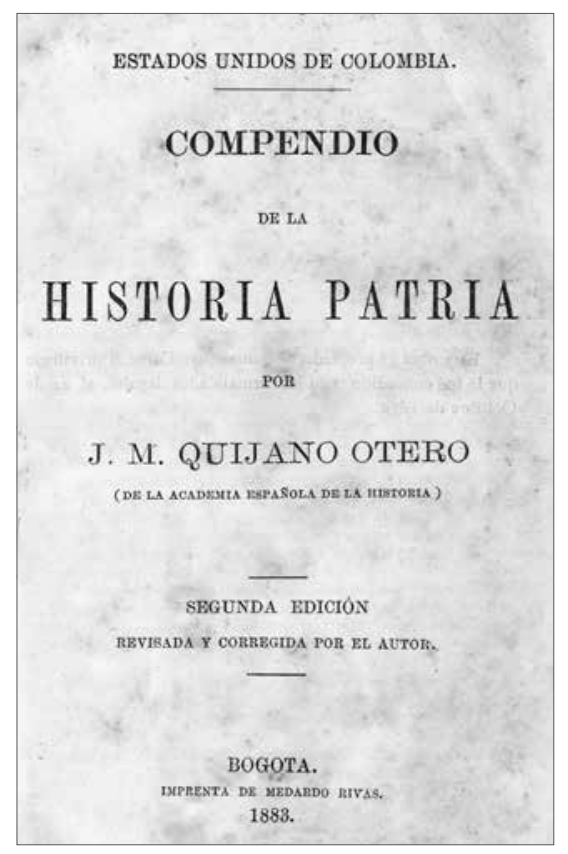

Imagen 6. Portadilla del texto escolar de José María Quijano Otero (1883), Compendio de Historia Patria. Para el uso de las escuelas primarias. Fuente: Sala de Patrimonio Documental. Biblioteca Universidad EAFIT 
Eran los tiempos de la restauración monárquica en Francia. Los borbones de la corte francesa volvían al poder después de las derrotas napoleónicas y, al hacerlo, tuvieron que resolver con cautela el sentimiento de lealtad familiar con el rey borbón español, de tal manera que pudieran, al mismo tiempo, reconocer la independencia de los nuevos Estados hispanoamericanos para desarrollar relaciones comerciales que les beneficiaran. Así lo narró José Manuel Restrepo (1781-1863), en la primera mitad del siglo XIX:

Este expuso [el diplomático francés Charles Bresson] los objetos de su misión, que eran: manifestar al gobierno de Colombia que el de S. M. cristianísima no había podido reconocer su independencia y la de las otras nuevas Repúblicas de la América antes española, por las relaciones íntimas de alianza y de sangre que lo ligaban con la familia reinante en España; en segundo lugar, por la delicadeza con que debía manejarse en tanto que sus tropas ocupaban y recorrían el territorio español, pero que sin embargo de tan graves obstáculos que encadenaban la política de la Francia, ésta en la primera ocasión que se le presentó había procurado establecer relaciones comerciales nombrando cónsules y agentes para Colombia (Restrepo, 2009b, p. 718).

Como Restrepo, José María Samper (1828-1888) tuvo presente, en sus Apuntamientos para la historia política i social de la Nueva Granada, los aportes franceses a los procesos de independencia, y a la construcción de una sociedad republicana y letrada en "HispanoColombia”, como él propuso denominar aquellas nuevas organizaciones sociales y políticas. Para Samper (1853), Francia "tiene en su revolución de 1789, una fecha que le enorgullece por sus gloriosos resultados" y se halla "preñada de elementos de civilización”, además, gracias a ella es posible admirar "la filosofía generosa de Rousseau, de Helvecio i Condorcet [y] los grandes heró́smos de la estupenda revolución francesa" (Samper, 1853, pp. 4-5). José María Samper (1853) consideraba que "la revolución colombiana" era un resultado obligado del "absolutismo colonial", "del tiempo que entraña siempre en su misterioso curso los cambios políticos i las épocas nuevas de los pueblos", pero era, ante todo, "una consecuencia forzosa de la revolución francesa" (p. 16). 


\section{HISTORIA}

DE LA REVOLUGION

De la Republica

\section{DE. COLOMIIA,}

Pon JOSÉ MANUEL RESTREPO,

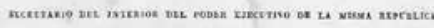

Ne dites a to postérité que ce quî es digne de ta posterith.

Voer, Hist, de Pierre-ie-Girand, Preiliee.

Xo digas a ra posteridad sise to gue es digro do la pest ridad.

comv primus.

發

PARIS,

LIBRERIA AMERICANA, CALLE DEL TEMPLE, $x^{\circ} 69$.

1827.

Imagen 7. Portadilla del texto de José Manuel Restrepo (1827).

Fuente: Sala de Patrimonio Documental. Biblioteca Universidad EAFIT

José María Samper fue uno de los primeros historiadores del siglo XIX neogranadino, y ejerciendo ese oficio construyó una narrativa antihispanista y afrancesada, para explicar los procesos de independencia y los cambios políticos con los cuales se tomaba partido por una u otra "tradición europea" (ver Imagen 8). ${ }^{4}$

En ese grupo de historiadores decimonónicos, se encontraba también José Antonio de Plaza (1807-1854), quien, narrando los acontecimientos de finales del siglo XVIII, aseguraba que "ocurrió por entonces un suceso que alarmó a las autoridades españolas, i que fue por decirlo así, la semilla que se sembró de la rejeneración política que debía brotar años después. D. Antonio Nariño, hombre ilustra-

4 Se pone entre comillas "tradición europea" porque, tal vez, sea necesario empezar a revisar lo que se llama europeo, con el fin de ver también en ello presencias culturales venidas de otros continentes. 
do, i que había cultivado su espíritu en el recinto de su gabinete, tradujo i dio a la prensa, de la obra francesa Historia de la asamblea constituyente, una parte de ella, que trataba de los Derechos del hombre" (De Plaza, 1850, p. 106). Sus palabras no fueron leídas únicamente por algunos eruditos o un pequeño círculo de letrados de Bogotá, donde fue editado e impreso su Compendio de la historia de la Nueva Granada, sino por un numeroso grupo de profesores y estudiantes, puesto que su texto se aprobó para "el uso de los colegios nacionales i particulares de la República", cuando la "Dirección jeneral de la instrucción pública” lo adoptó como texto de enseñanza. Su edición de 1850, conservada hoy en la Sala de Patrimonio Documental de EAFIT, salió de la Imprenta del Neogranadino (ver Imagen 9).

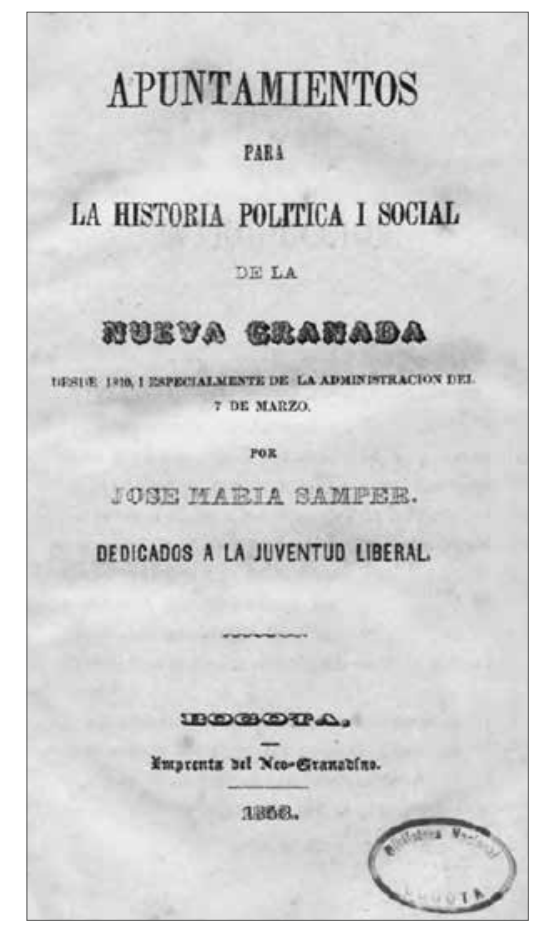

Imagen 8. Portadilla del texto de José María Samper (1853), Apuntamientos para la historia política i social de la Nueva Granada, desde 1810, i especialmente de la administración del 7 de marzo.

Fuente: Sala de Patrimonio Documental. Biblioteca Universidad EAFIT 


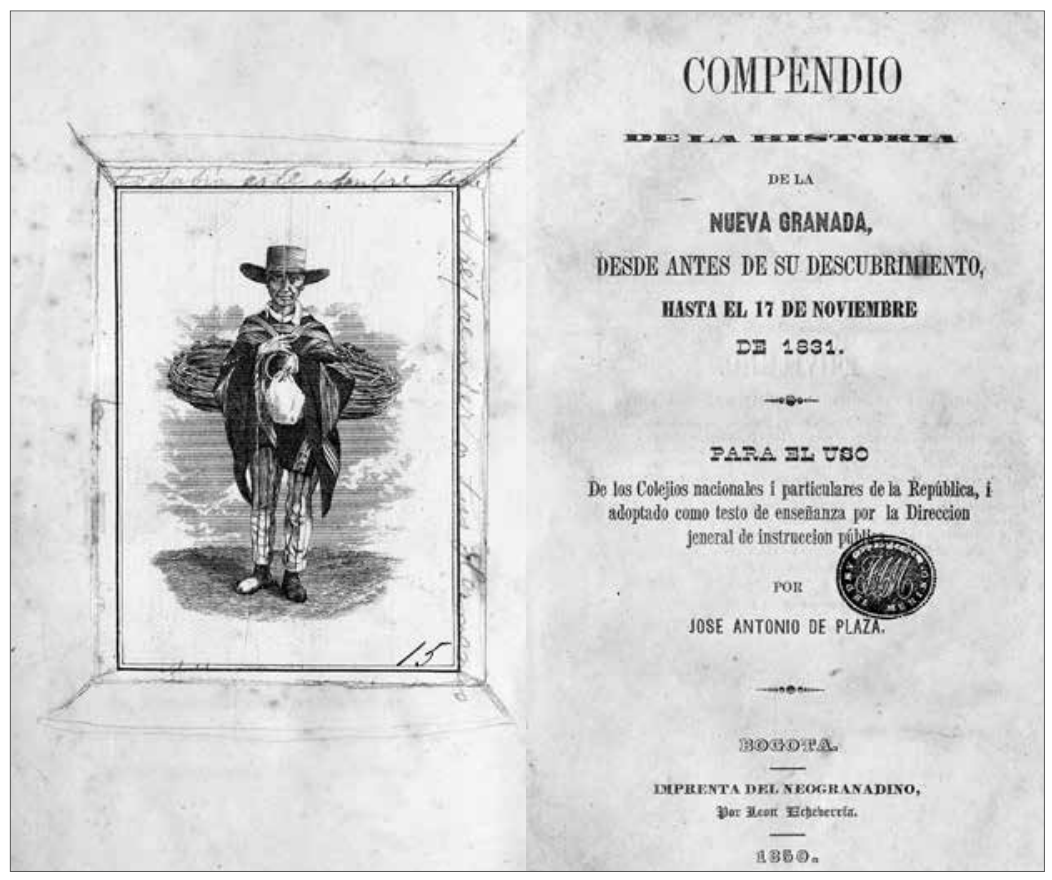

Imagen 9. Portadilla del texto de José Antonio de Plaza (1850), Compendio de la historia de la Nueva Granada,

desde antes de su descubrimiento, hasta el 17 de noviembre de 1831. Fuente: Sala de Patrimonio Documental. Biblioteca Universidad EAFIT

No obstante, el afrancesamiento tenía sus límites y adversarios. Entre los escritores de las historias de las independencias, hubo quienes aseguraban que las ideas y aspiraciones políticas de origen francés no eran positivas y benéficas para la América española. Ellas eran percibidas como peligrosas, portadoras de enfermedades y malestares sociales, capaces de destruir los valores más sagrados de la tradición cristiana. Un buen representante de esa perspectiva antifrancesa, antiliberal e hispanista fue José Manuel Groot (1800-1878), un neogranadino vinculado desde muy joven a las artes y las letras, quien vivió de cerca los acontecimientos separatistas y autonomistas mientras pintaba, y escribía poemas y relatos. Tuvo simpatías con la masonería y los cambios políticos que aseguraban la independencia de la Nueva Granada. También cultivaba sus capacidades como educador y sus conocimientos históricos, cuando abandonaba 
sus inclinaciones liberales e iniciaba un recorrido como publicista, fundando periódicos y escribiendo páginas en defensa de la religión (Groot, 1853; 1869a; 1869b; 1872; 1894). En dichos textos, usaba sus capacidades como escritor para combatir al liberalismo y al benthamismo, en particular por medio de su artículo llamado "Jesucristo o Bentham" (Groot, 1857).

Hacia 1860, José Manuel Groot era un consolidado intelectual conservador y un decidido historiador. Esta trayectoria lo llevó a investigar y a escribir una nueva historia de su país, conocida con el pomposo título de Historia eclesiástica y civil de la Nueva Granada, que, según su autor, fue "escrita sobre documentos auténticos", queriendo con ello dotar a su obra de un principio de verdad y credibilidad, muy acorde con la actitud positivista de los historiadores del siglo XIX, al considerar que los documentos eran fiel reflejo de las realidades del pasado (ver Imagen 10). Con ese trabajo, defendió su

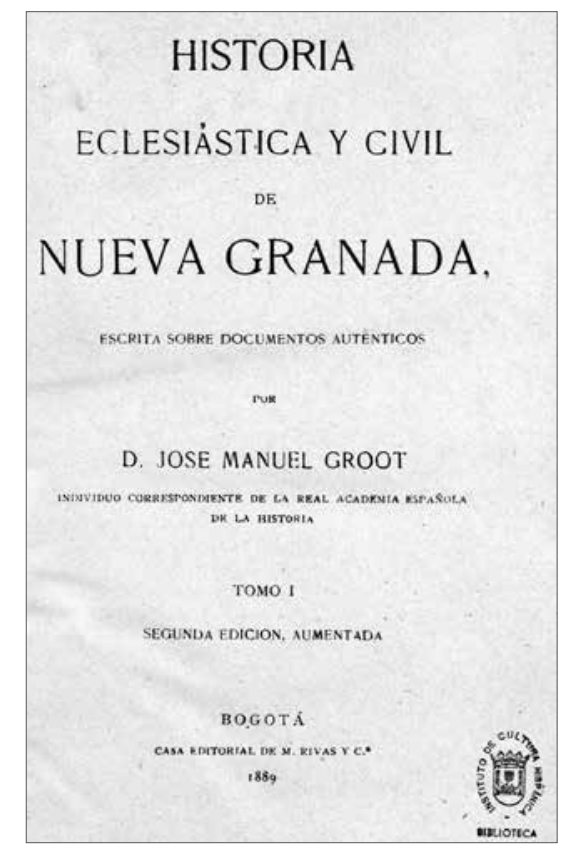

Imagen 10. Portadilla del Tomo 1 de la obra de José Manuel Groot

(1869c), Historia eclesiástica y civil de Nueva Granada, escrita sobre documentos auténticos.

Fuente: Sala de Patrimonio Documental. Biblioteca Universidad EAFIT 
simpatía con España y sus antipatías con Francia, territorio -este último- de donde venían "las ideas filosóficas revolucionarias [...], como pasan las pestes en las cobijas de los fardos" (Groot, 1869c, pp. 78). Con ellas llegaban también "las chispas del incendio prendido en Francia, [que] llevaban el fuego a todas partes" (Groot, 1869c, pp. 79). Estos peligrosos y dañinos flujos fueron los que permitieron a Antonio Nariño publicar la Declaración de los derechos del hombre y propagar, así, la contaminación de la que sufría debido a las ideas enciclopédicas (Groot, 1869c, p. 80).

En la Nueva Granada, durante el siglo XIX y frente a lo que había sucedido como consecuencia de las independencias hispanoamericanas, una arista se definió entre élites conservadoras cercanas a la permanencia o valoración de lo hispánico en lo americano y otros sectores elogiosos de lo francés en lo americano. Dos bandos: uno simpático a los cambios, llamado afrancesado, y otro hispanista, leal a la tradición católica española y resistente a los ímpetus revolucionarios que se sucedían en Francia.

En el núcleo de estas transformaciones y cambios, apareció una manifestación máxima del grupo afrancesado, es decir, la valoración de lo francés o latino en el contexto neogranadino, al instituir una denominación de identidad para la región ibérica: América Latina, defendida por el redactor político de El Correo de Ultramar, el diplomático y poeta José María Torres Caicedo (1830-1889). Este clásico afrancesado, nacido en Nueva Granada, escribió una oda política, llamada Les príncipes de 1789 en Amérique, una obra histórica titulada Colonisation des deux Amériques (Colonización de las dos Américas), para diferenciar las dos presencias europeas al otro lado del Atlántico (anglosajona y latina), y se puso al frente del proyecto denominado Unión Latino-Americana. Tomando a Francia como el referente fundacional de esta soñada entidad política, aseguraba que "el siglo pasado [XVIII], la Revolución de 1789 puso las bases de la organización del futuro después de que las armas de la Francia ayudaran a constituir la república anglo-sajona al otro lado del Atlántico. Un poco más tarde, todas las naciones del continente estaban sometidas a la influencia, al poder y a las leyes de una nación latina" (Torres Caicedo, 1882, p. 24). En este último sentido, Torres Caicedo, elogiando el Siglo de las Luces, afirmaba, desde su lugar en la élite hispanoamericana afrancesada, la aceptación de otro tipo de 
imaginario político de sometimiento, ya no el de las armas o la fuerza, sino aquel que venía de la cultura, las leyes y la política, y que se expresaba en una nueva legitimidad que era la república.

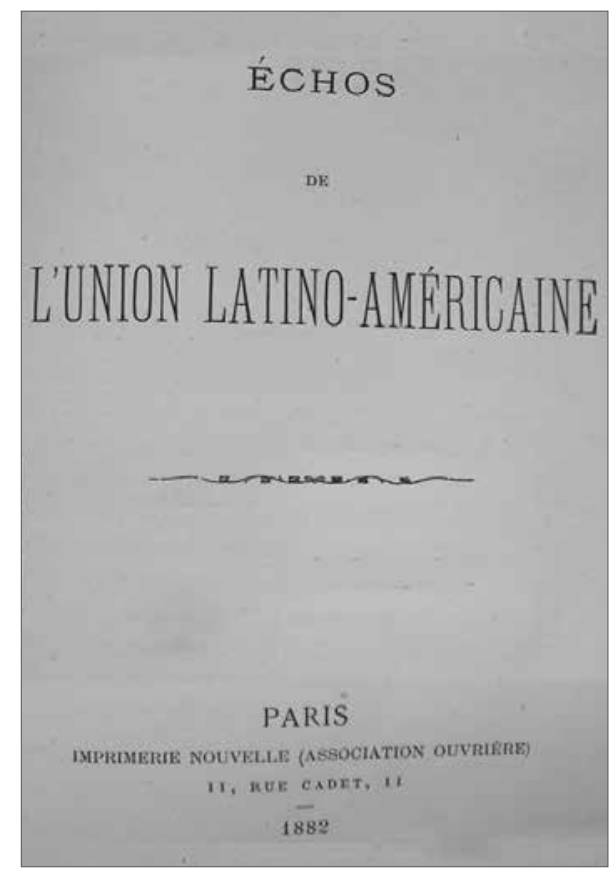

Imagen 11. Portadilla del libro de José María Torres Caicedo (1882), Echos de L’Union Latinoaméricaine. Fuente: Biblioteca Nacional de Colombia

Desde distintas expresiones, las élites hispanoamericanas afrancesadas calificaban a Francia, y sus giros políticos y culturales con adjetivos superlativos y apologéticos. Lo que sucedía en el país galo se convertía, con frecuencia, en medida y patrón, era admirado con sentimientos de filiación materna y servía para inspirar la creación de un imaginario de identidad latinoamericano. Así como lo hacía, desde París, el intelectual José María Torres Caicedo durante la segunda mitad del siglo XIX, lo hizo, en la primera mitad del XX, desde diversos lugares de América del Sur, el hombre de letras Manuel María Buenaventura (1880-i?). Apoyado y rodeado por una comunidad latinoamericana de afrancesados, dio gracias a Francia 
por ser "guion de la raza latina, madre de nuestra cultura" y porque "nos inspiráis en todo momento gratitud, admiración, respeto y amor" (Buenaventura, 1946, p. 92). Buenaventura (1946) hacía un reconocimiento múltiple y planetario, pues "el mundo, debido a la Revolución Francesa, cambiaba de rumbo, al abrir los caminos de la democracia” (p. 90).
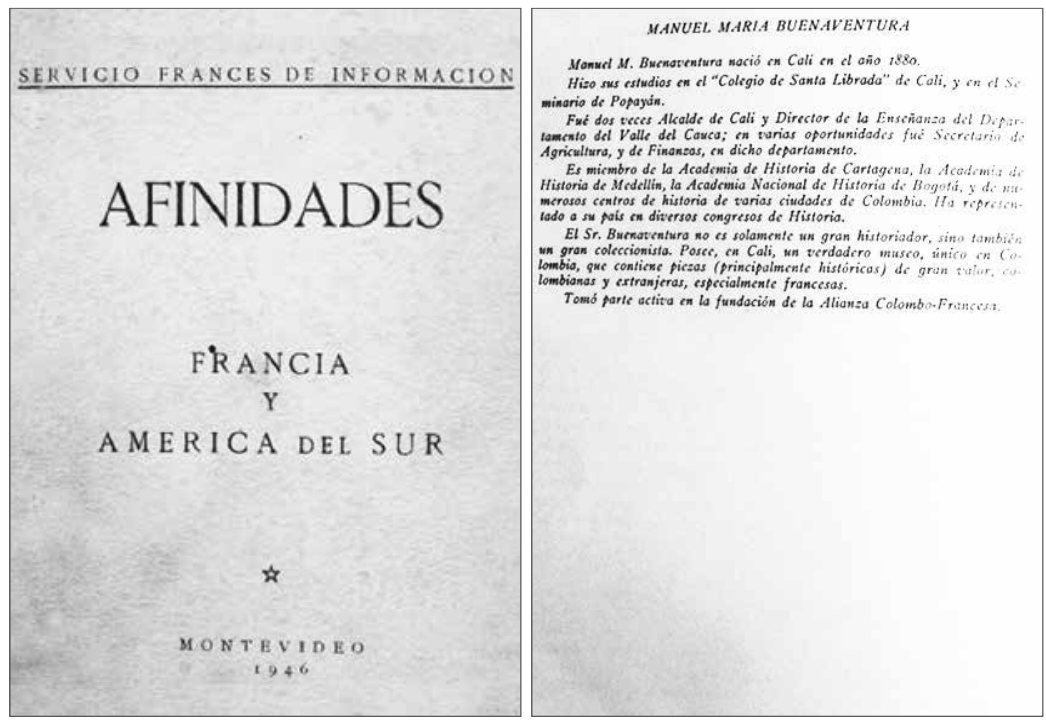

Imagen 12. Portada del texto de Manuel María Buenaventura (1946). Fuente: Biblioteca Nacional de Colombia

Estos procesos de identificación latina fueron llevados a cabo por estos dos intelectuales colombianos en escenarios académicos, políticos y temporales diferentes: uno desde la diplomacia en Europa durante el siglo XIX; y el otro, en el Servicio Francés de Información en América del Sur, en el siglo xx, pero coincidían en exaltar, mitificar y darle a Francia y a sus acciones políticas las valoraciones más altas en consideraciones civiles e históricas; en una especie de sacralización política de los procesos que hicieron posible fundar lo que se conoce como América Latina.

Con esas declaraciones, no es el eurocentrismo el que se promovía, sino el francocentrismo. De acuerdo con Buenaventura (1946), de Francia brotaron dos de los valores más preciados del 
mundo -en ese momento-, pues aseguraba que "con lo dicho queda comprobado que la independencia y libertad, muy especialmente para nosotros, vinieron de Francia” (p. 92). De ese país también surgió un maravilloso código civil, que "fue la piedra angular de toda la vida civil americana” (Buenaventura, 1946, p. 92). En este sentido, la acción legislativa refrendaba una identidad cultural, una independencia política y una institucionalidad organizada según el canon moderno de los territorios otrora sin autonomía codificadora. Los afrancesados veían una sola ruta: la que irradiaba y emanaba, desde París, ideas e instituciones, artes y letras, ciencias y saberes. Primaba en ellos una unidireccionalidad que impedía ver la compleja e interesante variedad de direcciones que construía los procesos de modernización en un mundo globalizado. ${ }^{5}$ Un ejemplo más del exacerbado francocentrismo de Manuel María Buenaventura (1946) puede verse en las siguientes líneas que piensan la historia del café en América: "aquel arbusto de la Martinica [el cafeto], fue el padre común de los millones de arbustos que han poblado las grandes plantaciones de América” (p. 92). En resumen, este afrancesamiento, que con frecuencia vanagloriaba el nacionalismo francés, opacando las complejas redes de mundialización política que se habían producido, fue muy común en el siglo XIX.

Sin embargo, como se ha visto a través de Manuel María Buenaventura, del servicio francés de información y del texto Afinidades Francia y América del sur (Servicio Francés de Información, 1946), durante el siglo xx persistió el afrancesamiento entre numerosos escritores. Aquel libro, publicado en Montevideo, Uruguay, fue realizado con la participación de autores de diez países hispanoamericanos: Argentina, Bolivia, Brasil, Chile, Colombia, Ecuador, Paraguay, Perú, Uruguay y Venezuela. Además del capítulo de Manuel María Buenaventura, "Influencia de Francia en la Independencia de Colombia, y después en su economía”, se encuentran textos como: "Participación francesa en la hora de la emancipación y en la formación política de Bolivia”, escrito por Antonio

5 Para ver con más detalle esta crítica al francocentrismo, ver los libros de Serge Gruzinski (2018), y Juan Camilo Escobar Villegas y Adolfo León Maya Salazar (2011). 
Díaz Villamil; "Lumbres en la historia: Francia en el curso de la emancipación americana”, del venezolano José Miguel Ferrer; y el capítulo del paraguayo Luis A. Argaña, planteando la pregunta: "¿Cuál ha sido la participación francesa en la obra de la liberación y formación política del Paraguay?” (Servicio Francés de Información, 1946).

Unos años después, en 1954, se publicó en Bogotá un texto del escritor colombiano Rafael Maya (1897-1980), en el cual se planteaba un nuevo caso de afrancesamiento. Para este poeta y crítico literario, quien usaba una retórica racial y religiosa, era evidente y necesario acudir, una vez más, a la guía espiritual francesa. En efecto, Maya (1954) decía: "Quiera el cielo que no perdamos nunca los grandes principios orientadores de la raza, y que la claridad latina, a cuya permanencia ha contribuido Francia con los eternos luminares de su espíritu, nos guíen en medio de las tinieblas que acaso se aproximan" (p. 435). ${ }^{6}$ Eran los tiempos de la violencia política liberal en Colombia y, para enfrentar la tragedia mortal que recorría el país, el intelectual afrancesado acudía al "cielo", a la "raza” y a Francia, con la esperanza de que esa triple combinación ayudara a salir de "las tinieblas".

\section{Subvaloración de la cultura hispánica en favor de la latina}

Los procesos de independencia en Hispanoamérica y su consecuente creación de nuevas entidades políticas, con autonomía para relacionarse en el ámbito internacional, activaron imaginarios de identidad, en Europa, que se habían construido durante las frecuentes y largas guerras entre franceses, ingleses, germanos, escandinavos, españoles, portugueses y otros pueblos de los tiempos medievales y modernos. Relacionarse con "las nuevas Américas" provocó, rápidamente, en los países europeos, donde el capitalismo y el comercio internacional tenían mayor desarrollo, un marcado interés por narrar, escribir y explicar el pasado, presente y futuro de las repúblicas que surgían de la

6 Lectura hecha por Maya en la sala de conferencias de la Alianza Colombo-Francesa, el 27 de mayo de 1953. 
derrota militar del imperio español en América. Este esfuerzo intelectual, literario, editorial y narrativo fue llevado a cabo por diversos profesionales. Entre ellos, participaron Alfred Deberle, periodista y autor de libros de teatro y literatura infantil; el clérigo y profesor de filosofía Paul Guerin; el ingeniero y geógrafo François Bianconi; el profesor políglota de origen ruso Boris Mirkine-Guetzevitch, y gente de industria y Estado, como el industrial, inversionista y cónsul francés Georges Aubert.

Las palabras de estos profesionales portaban el esfuerzo de la objetividad histórica y científica, pero también la impronta de lo que pensaban de sí mismos como miembros de una de esas "comunidades imaginadas" o "artefactos culturales" que Benedict Anderson (1993) ha estudiado. De manera lógica y complementaria, estos autores proponían palabras, nociones y conceptos para definir a los otros, para ofrecer una narrativa de la alteridad. Los autores de origen francés que se han encontrado en los anaqueles de la Biblioteca Nacional de Colombia, ${ }^{?}$ interesados en narrar y explicar lo sucedido en Hispanoamérica, hicieron una operación historiográfica con la cual hablaban de hispanoamericanos, así como de europeos. Era, tal vez, necesario tanto en los terrenos de la política y la economía, como en el ámbito cultural, en el de las representaciones, pues en él se definía quiénes podían ser los nuevos mejores aliados. De esa forma, escribir la historia de otros condujo, frecuentemente, a escribir la historia de sí mismo. Detrás de las páginas sobre las guerras de las independencias americanas aparecían, como un fantasma, las guerras nacionalistas, territoriales, comerciales y estatales europeas.

En los textos de estos autores, España y su intervención en América, desde finales del siglo XV, son valoradas negativamente. Podría decirse que estas explicaciones nutren la conocida "leyenda negra" de la conquista ibérica en el continente. De esa forma, la conquista española de territorios y poblaciones americanas no significó lo que otra versión, la de la "leyenda rosa", ha asegurado en cuanto a "los beneficios de la conquista española en América", como escribió Ernesto Restrepo Tirado (1929). En efecto, para Alfred Deberle

7 Las principales fuentes han sido aquellas revisadas en la Biblioteca Nacional de Colombia. No obstante, como se señaló en varios pasajes del texto, estas representaciones mentales de los autores franceses y afrancesados se refieren al conjunto territorial que ellos empezaron a llamar América Latina. 
(1876), "España, que durante tres siglos tuvo esclavizada y atada a sus pies a América, fue quien le inoculó sus supersticiones y sus vicios. Uno no se libra en un día de tres siglos de opresión" (p. iii).

Esta figura nociva, que explicaba cómo actuó España en América, tenía un sentido metafórico que conducía al lector al inicio de una epidemia, de una infestación que recorría un continente, malogrando sus poblaciones para poder dominarlas mejor. Ahora bien, la maldad no llegó a España de tierras extrañas, sino que era propia de ellos, estaba en la naturaleza de esos conquistadores y gobernantes que no conocían otro lenguaje que el de la esclavitud, la superchería y el vicio. Las guerras francoespañolas que tuvieron tantos escenarios en la geografía europea y americana, desde los enfrentamientos frecuentes en los mares atlánticos entre los "piratas" franceses y las autoridades españolas, poseían ahora un nuevo territorio: el de la narración histórica.

Por esta razón, el autor francés Alfred Deberle, algunas líneas después de la subvaloración de la tradición hispánica en América, promovió y defendió un mayor esfuerzo en Francia, con el fin de escribir con rigor una historia en la que se comprendiera la epopeya que llevó al continente americano de la opresión hispánica a la liberación francesa. En ese proyecto, advertía que "Francia olvida demasiado que ella fue para esos pueblos una iniciadora, que la Declaración de los derechos del hombre fue un evangelio para su resurrección, que ellos giraban hacia ella sus miradas mientras combatían por la liberación" (Deberle, 1876, p. 18). Estas reflexiones de 1876 fueron secundadas, en 1901, por el diplomático y financiero francés Georges Aubert (1901), en su libro Las nuevas Américas. Notas sociales y económicas. Estados Unidos, México, Cuba, Colombia, Guatemala, etc. Allí asegura que "después de que Colombia se sacudió en 1819, de la terrible dominación española, y ella ha reconquistado su independencia, uno cuenta en ese país alrededor de 55 revoluciones" (p. 256). De cierta forma, esa numerosa conflictividad e inestabilidad política, a los ojos de estos autores franceses, se podía comprender por las fuertes y resistentes tradiciones hispánicas que crearon gente revoltosa, acalorada e irracional durante los trescientos años de dominación y oscurantismo. 
En efecto, Georges Aubert (1901) consideraba que, en Colombia, pero también en el resto de los países originados por la presencia de lo hispánico, existía una gran dificultad para aclimatar plenamente y de forma exitosa los grandes valores latinos, es decir, la tradición francesa de libertad, igualdad y fraternidad, porque en "ese país, uno está tentado a creer que todos los males que allí se sufren provienen justamente de esta evolución demasiado rápida de los espíritus ardientes e impetuosos" (p. 257). ¿De dónde procedían, entonces, esos espíritus incapaces de la calma y la racionalidad, espíritus funestos para construir parabienes que permitieran el "progreso" y la "civilización", o el establecimiento definitivo de repúblicas en las cuales el pueblo fuera soberano y capaz de controlar y orientar sus ímpetus?

Este interrogante podría contestarse con palabras de Alfred Deberle, compatriota de Aubert, puesto que este último, consejero del comercio exterior de Francia, también Medalla de oro de la Sociedad de geografía comercial de París, estaría muy acorde con ellas, dado que también veía en la forma de la presencia hispánica en América una explicación de lo que había sucedido en el Nuevo Mundo durante el siglo XIX. Decía Alfred Deberle (1876) que "España perdió por todas partes los países ricos donde ella hasta hace poco había mandado sin descanso, esa vergonzosa derrota fue la justa expiación de su conducta respecto a los pueblos que ella tiranizó cruelmente" (p. 111). En otros términos, estos autores franceses estaban haciendo una lectura del pasado conquistador y colonial hispánico en América desde un tribunal que era capaz de impartir justicia al "nuevo presente".

España, según estos autores, debía ser juzgada en este otro escenario de enfrentamientos narrativos y calificativos, porque la forma como actuó en los territorios americanos no liberaba, sino que tiranizaba. De allí que lo más prudente y necesario fuera ofrecer "las luces del gran pueblo latino" (Buenaventura, 1946, p. 92), como llamaba el afrancesado Manuel María Buenaventura a la sociedad francesa, porque esas "luces" representan la posibilidad de una segunda oportunidad para América. Como se puede ver en el siguiente apartado, esta lectura frecuente de los procesos históricos americanos, realizada por un importante número de autores franceses del siglo XIX, presentaba las "luces latinas", las que iluminaban desde París, 
ligadas a los esfuerzos por construir un nuevo sistema de relaciones internacionales entre Europa y América. En este texto, se presenta el lado francés, la vertiente francesa que aprovechaba sus imaginarios de identidad nacional para narrar la historia euroamericana. Queda pendiente, para un texto posterior, presentar la narración inglesa y comprender las "luces anglosajonas", al lado de las justificaciones que construían los autores británicos del siglo XIX, sobre lo que hizo posible la aparición de las independencias hispanoamericanas.

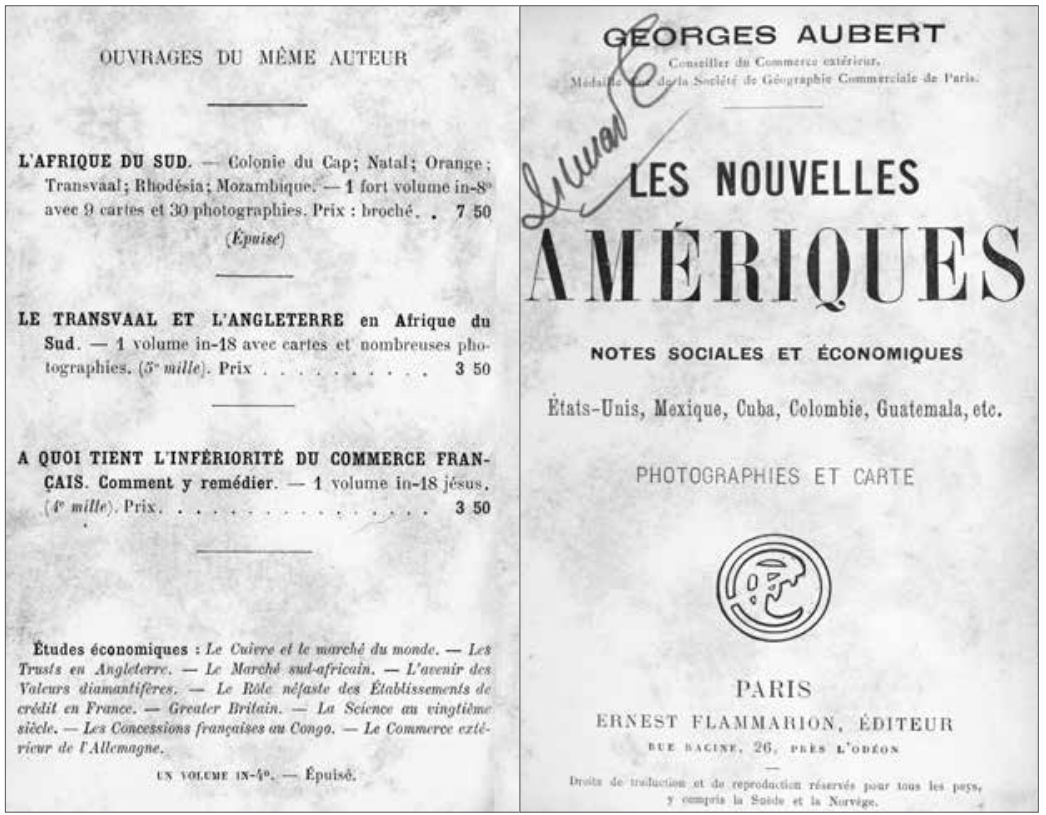

Imagen 13. Portadilla de Les nouvelles Amériques, notes sociales et économiques (Aubert, 1901), y títulos de otras obras de Georges Aubert. Fuente: Sala de Patrimonio Documental. Biblioteca Universidad EAFIT

Para terminar las reflexiones sobre estas "luces latinas" que estaban inventando los escritores y diplomáticos franceses, en compañía de algunos afrancesados, cabe recordar las consideraciones que escribió el político e historiador José María Samper, liberal a mediados del siglo XIX, y conservador unas décadas después. Ellas son importantes para comprender el grado de subvaloración de la cultura hispánica, en medio de las luchas de imaginarios de identidad que participaban 
al momento de explicar las razones de las independencias hispanoamericanas. Según Samper (1853), la "raza española" o "el espíritu jenial del pueblo español" es "abyecto i perezoso cuando obedece; cruel i sanguinario cuando manda; inconsecuente i codicioso siempre, $\mathrm{i}$ apegado a las doctrinas tradicionales, aborrece la libertad por ignorancia, i ama la obediencia pasiva i el statu quo por costumbre" (p. 27). Para él, ese espíritu español se aterra ante la palabra refor$m a$, porque vive siempre en el pasado y desconoce el significado del futuro. Estas palabras, en el contexto, servían a favor de la llamada cultura latina, y justificaban el nuevo denominador que había puesto a circular Michel Chevalier: el de América Latina.

Los órdenes políticos del Nuevo Mundo necesitaban apoyarse, entonces, en otras tradiciones que borraran las costumbres hispánicas, y respaldarse con nuevas propuestas que cultivaran otra esencia, porque, según José María Samper (1853), si un español siguiera gobernando en Colombia "daría proclamas en vez de reglas de gobierno, versos en lugar de buenas leyes, i piadosas novenas para pedir a los Santos que organicen convenientemente los poderes públicos" (p. 27). Este retrato de los españoles, de la hispanidad, obligaba a dirigir la mirada a otros horizontes, a crear nuevas amistades y relaciones internacionales, a ver llegar otras banderas a los puertos libres de América, pues la española, de acuerdo con Samper (1853), estaría constituida por "una camándula para representar su fanatismo, una cadena para expresar su servilismo, i una bolsa para demostrar la codicia de un alcabalero" (p. 28). Como lo explicaba este joven liberal radical, "los franceses, que aman i comprenden la República, se empeñan a porfía en crear la historia de sus tiempos" (Samper, 1853, p. 5), y así lo llevaron a cabo a través de la exitosa combinación de narraciones históricas, relaciones diplomáticas y colonialismos de diverso grado.

\section{Legitimación de los colonialismos franceses}

Se ha dicho que, detrás de los textos y las reflexiones de los autores franceses del siglo XIX, recopilados para este artículo, existen varias líneas narrativas o, como se propone aquí, una serie de constataciones conceptuales que permiten aproximarse a ciertas lecturas 
francesas de las independencias hispanoamericanas, o latinoamericanas, dado que uno de los logros de los autores franceses del siglo XIX fue haber institucionalizado y oficializado, para las antiguas colonias iberoamericanas y francesas -incluyendo Brasil, Haití y otros territorios- el nombre Latinoamérica. Este triunfo hizo entrar a Francia en la conformación cultural de los pueblos, países, naciones y Estados conocidos como latinoamericanos. Por eso, el Diccionario de la lengua española (Real Academia Española, 2014) mantiene hoy la siguiente definición para la entrada América Latina: "conjunto de países americanos que fueron colonizados por naciones latinas, es decir: España, Portugal o Francia".

Podría decirse que Francia colonizó, por medio de sus escritoresdiplomáticos del siglo XIX, el territorio toponímico de los diccionarios. Lo hizo poniendo en funcionamiento las racionalidades analíticas que se han presentado en los anteriores apartados y que se presentarán en este. Exaltando las ideas ilustradas de "origen francés”, describiendo la Revolución Francesa y su Declaración de los derechos del hombre y del ciudadano como modelo a seguir, estimulando el afrancesamiento de las élites intelectuales del mundo, subvalorando otras culturas europeas en favor de valorar la que ellos empezaron a llamar "latina" y estableciendo convenios, acuerdos, tratados y alianzas para favorecer la presencia de la llamada "civilización francesa", Francia logró afianzar, canonizar e instituir un paradigma que se irrigó en textos escolares y en imaginarios de origen que le han dado a las artes y las letras francesas un atractivo especial. También abrieron puertas para impulsar su comercio y fortalecer un sistema internacional de relaciones en el cual el Estado francés podía obtener beneficios y liderar alianzas y transformaciones socioculturales que, con frecuencia, estimulaban la amistad de muchos pueblos del planeta con esta sociedad.

Es importante decir que estas escrituras francesas del siglo XIX sobre las independencias hispanoamericanas no fueron dominantes en el siglo posterior, particularmente en los círculos académicos de los historiadores franceses vinculados a la Escuela de Los Annales y a lo que décadas después se denominó la Nueva Historia, de la que también han hecho parte diferentes corrientes historiográficas del mundo. La importancia de la Revolución Francesa y de las ideas 
ilustradas sigue siendo estudiada, pero en perspectivas críticas que ponderan mejor su lugar en los procesos de mundialización de la modernidad política. Estas otras lecturas francesas de las revoluciones liberales e independentistas en el mundo han dado un giro analítico e historiográfico, al distanciarse de los intereses geopolíticos y geoeconómicos del Estado francés.

Esta distancia entre Estado y academia parecía ser imposible en el siglo XIX. El funcionario, el diplomático o el negociador internacional que se desplazaba por el mundo, en nombre del Estado francés y de la "civilización francesa", llevaba consigo los textos que se han venido presentado y al mismo tiempo podía, él mismo, producir nuevas publicaciones que interpretaban el pasado de las regiones intervenidas y representaban, a los ojos de sus nuevos aliados, una sobrevaloración de las trayectorias de los procesos de la modernidad en Francia.

Se denomina "procesos de la modernidad" al trabajo que se ha venido haciendo desde el siglo XVI por construir un modelo de sujetos y sociedades en los cuales predominan ciertos valores socioculturales. Entre ellos, se puede destacar la racionalidad científica, la responsabilidad individual, la defensa de principios políticos republicanos y democráticos, la promoción del libre mercado regulado por el bien público, y aspectos recientes como el pacifismo y la tolerancia a la diversidad, en el marco de los derechos humanos aceptados por la Organización de las Naciones Unidas. Este modelo ha sido dinámico, se ha transformado y expresado como un imaginario de una totalidad social, específicamente en los articulados de las constituciones políticas que han venido creándose desde el siglo XVIII, alrededor del mundo. Francia ha sido protagonista de los procesos de mundialización de este modelo de modernidad, pero no ha estado sola. En ellos han participado pueblos de los cinco continentes, difundiendo, adaptando y creando elementos que circulan por el planeta por diferentes medios y en diversas intensidades.

Hay que insistir en que el protagonismo francés en los diferentes procesos de mundialización y globalización ha sido vinculado a los tiempos conocidos como la época del imperialismo, de acuerdo con el texto de Wolfgang Mommsen (1969). Se trataba del último cuarto del siglo XIX y del primero del XX. No obstante, esos procesos imperiales y coloniales de los países europeos cubren tiempos más 
largos. Lo que se hizo en la Conferencia de Berlín en 1884 y 1885 formalizó el reparto de África después de que ya se habían llevado a cabo las posesiones, dominaciones y ocupaciones de la gran mayoría de los territorios de este continente desde décadas atrás. Según el acta que firmaron en Berlín los catorce representantes de las llamadas potencias mundiales, ${ }^{8}$ el objetivo de dicha reunión, a la que no asistió ningún representante africano, era "en un espíritu de mutuo acuerdo, regular las condiciones más favorables para el desarrollo del comercio y la civilización en ciertas regiones de África, y para asegurar a todas las naciones las ventajas de la libre navegación de los dos principales ríos de África, que fluyen en el Océano Atlántico" (“Acta General”, 1885). La reunión, el acuerdo y la firma de un acta legitimaban los colonialismos europeos en África, invocando el "desarrollo del comercio y la civilización" y "en el nombre de Dios Todopoderoso".

Comerciar, dominar pueblos y rutas, extraer materias primas para el impulso de las industrias europeas y el enriquecimiento de ciertos grupos sociales era posible, siempre y cuando se entregara a cambio lo que estos colonizadores llamaban "civilización". Palabra ambigua con la cual se ofrecían ideales socioculturales que se consideraban superiores a los de esos pueblos africanos "incivilizados". Estas lógicas ideológicas, de poderosos efectos políticos y económicos en favor de Europa, se venían utilizando también, como se ha indicado, para establecer y fortalecer las relaciones de Francia con los países americanos.

Alfred Deberle llamaba la atención a los franceses, en 1876, para que hubiera un mayor interés en los pueblos de América del Sur, pues consideraba que en ese presente "Europa parece comprender mejor el provecho que puede recibir de entablar relaciones amigables con

8 Los siguientes fueron los firmantes del Acta: Su Majestad la Reina del Reino Unido de Gran Bretaña e Irlanda, Emperatriz de la India; Su Majestad el Emperador de Alemania, Rey de Prusia; Su Majestad el Emperador de Austria, rey de Bohemia, etc., y Rey Apostólico de Hungría; Su Majestad el Rey de los Belgas; Su Majestad el Rey de Dinamarca; Su Majestad el Rey de España; el Presidente de los Estados Unidos de América; el Presidente de la República Francesa; Su Majestad el Rey de Italia; Su Majestad el Rey de los Países Bajos, Gran Duque de Luxemburgo, etc.; Su Majestad el Rey de Portugal y Algarves, etc.; Su Majestad el Emperador de todas las Rusias; Su Majestad el Rey de Suecia y Noruega, etc.; y Su Majestad el Emperador de los Otomanos (“Acta General", 1885). 
América Latina" (1876, p. IV). Eran los tiempos en los cuales las potencias imperiales europeas buscaban recursos por el mundo entero, usando la diplomacia, pero también las armas. Por eso, Deberle se lamentaba, pues Francia "sólo se interesa a medias por los hechos distantes" (1876, p. IV). La respuesta no tardó: vinieron los mapas comerciales o Les cartes comerciales, sobre los cuales ya se han hecho algunas reflexiones.

En esa lógica de interesarse por lo que sucedía lejos de París, los gobiernos franceses, con la guía de la Asamblea Nacional y bajo la égida de la Tercera República (1878-1940), continuaron buscando diferentes formas de asegurar su condición de "potencia mundial" e impulsar su proceso de industrialización. Como se expuso antes, la alianza entre diplomáticos, gobernantes e intelectuales produjo una serie de documentos conocida como Cartes commerciales o Colección de estudios generales geográficos. Dichos mapas comerciales se publicaron durante las dos últimas décadas del siglo XIX. El que se dedicó a Colombia y Ecuador circuló a partir de 1887 e incluía un "planisferio especial que indica los futuros itinerarios por el Canal de Panamá" (Bianconi y Broc, 1887).

En esta publicación, François Bianconi y E. Broc (1887) alentaban a los comerciantes franceses con el fin de buscar "buenas oportunidades en estos países latinos de América del Sur, donde sus transacciones pueden desarrollarse fácilmente gracias a la simpatía tan sincera que encuentran entre las poblaciones de estos vastos y ricos países" (p. 5). Consideraban los autores que el comercio francés "debe beneficiarse principalmente de la apertura del Canal de Panamá" (Bianconi y Broc, 1887, p. 5). El gobierno francés, la organización de Ferdinand de Lesseps, la Sociedad de Geografía de París y la opinión pública francesa estuvieron muy atentos al desarrollo del proyecto de construcción de este canal, así como los comerciantes que estaban suscritos a la Colección de mapas comerciales que informaban de opciones de negocias en diversas partes del mundo, los cuales contaban con la simpatía de los habitantes de las vastas tierras por donde se había irrigado, según las frecuentes lecturas francesas, la fuerza de las ideas ilustradas, libertarias y civilizadoras que tuvieron origen en Francia. La política exterior de este país conjugaba con maestría los logros de sus filósofos iluministas, su pueblo revolucionario, y sus 
funcionarios y comerciantes vinculados a la Subsecretaría de Estado de las colonias, así como a las diferentes cámaras de comercio existentes en sus territorios. El lenguaje que acompañaba dicha política de relaciones internacionales aseguraba, con frecuencia, que América debía a Francia su "sagrada libertad" y su "nueva civilización".

Los inicios del siglo XX vieron consolidar las relaciones internacionales de Francia con Latinoamérica a través de un nuevo organismo: el Comité Francia-América. Fundada en 1909, esta institución promovía la intensificación de las relaciones con los países americanos dentro de un programa estatal que tenía, además, otras dos líneas de acción: una en África y otra en Asia. En efecto, de acuerdo con su presidente, Gabriel Hanotaux (1925), miembro también de la Academia Francesa, "desde que Francia fue relevada, después de la guerra de 1870, varios deberes urgentes se le impusieron [...]. Debía retomar su rango de gran potencia y terminar con el descrédito mantenido por sus adversarios" (p. 211). Se trataba, en otros términos, de reaccionar ante un orden mundial que veía crecer dos nuevos rivales en el control de las redes comerciales mundiales: los Estados Unidos de América y la Alemania vencedora de la guerra franco-prusiana de 1870.

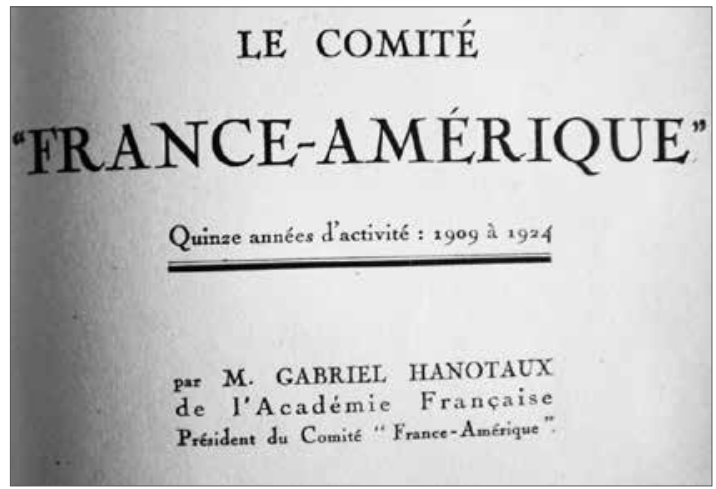

Imagen 14. Página interior del texto de F. Bianconi y E. Broc (1887), Colombie et Équateur, Collection des études générales géographiques, Cartes commerciales. Fuente: Biblioteca Nacional de Colombia

Para el director del Comité Francia-América, "la pregunta que se planteaba era saber si Francia asistiría impotente al reparto del 
Universo, o si ella reclamaría en él la parte que su alta misión civilizadora debía reservarle" (Hanotaux, 1925, p. 211). Esa parte del planeta que Francia, a través de estos diplomáticos eruditos, consideraba debía gravitar en torno suyo, fue consolidándose por una sistemática y constante acción política que lograba, en algunas ocasiones, acuerdos con líderes de diferentes pueblos del mundo, como el Tratado Salgar-Wyse, que otorgaba a ciertos grupos franceses el derecho a construir el Canal de Panamá y su usufructo durante 99 años. ${ }^{9}$

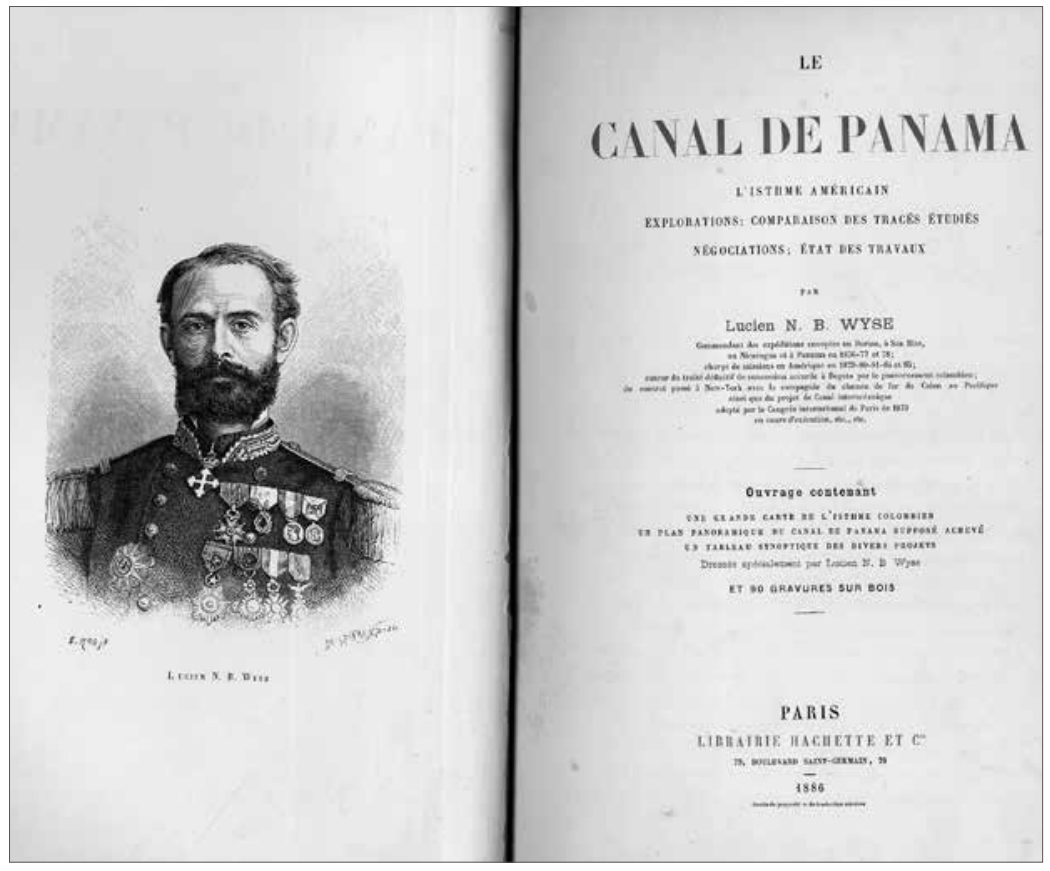

Imagen 15. Portada de la publicación realizada por Lucien Napoléon Bonaparte Wyse (1886), Le Canal de Panamá: L'isthme Américain explorations, comparaison des tracés étudiés, négociations, état des travaux. Fuente: Sala de Patrimonio Documental. Biblioteca Universidad EAFIT.

9 Ver, en la Biblioteca Nacional de Colombia, el libro del comandante de las expediciones enviadas al Darién (Bonaparte Wyse, 1886). Ver también los siguientes enlaces: http:// catalogoenlinea.bibliotecanacional.gov.co/client/es_ES/search/asset/6607/0; http://bibliotecanacional.gov.co/es-co/colecciones/biblioteca-digital/publicacion?nombre=El+canal $+\mathrm{d}$ e+Panam\%C3\%A1:+exploraciones+del+istmo 
En otras ocasiones, fue menos diplomática la reclamación que Francia hizo de algunos territorios, como su incursión en México cuando impuso, por la fuerza, un gobernante: el malogrado archiduque Maximiliano de Habsburgo. La historia de sus dominios en África y Asia fueron también una mezcla de diplomacia y acciones militares. Este imaginario de dominación política y expansión global estuvo acompañado de constantes referencias al sistema de ideas e instituciones liberales, republicanas y democráticas que Francia había logrado para sí después de la Revolución Francesa. Sus conquistas territoriales, según Hanotaux (1925), fueron "política de Estado". Con ella, lograron "la conquista de Indo-China", "la constitución del imperio colonial africano" y el aseguramiento de "las relaciones cordiales entre el nuevo continente y Francia” (pp. 211-212). Para esta última tarea, se había creado el Comité Francia-América, según el informe que se publicó, en 1925, para celebrar los quince años de actividad de este organismo (Hanotaux, 1925).

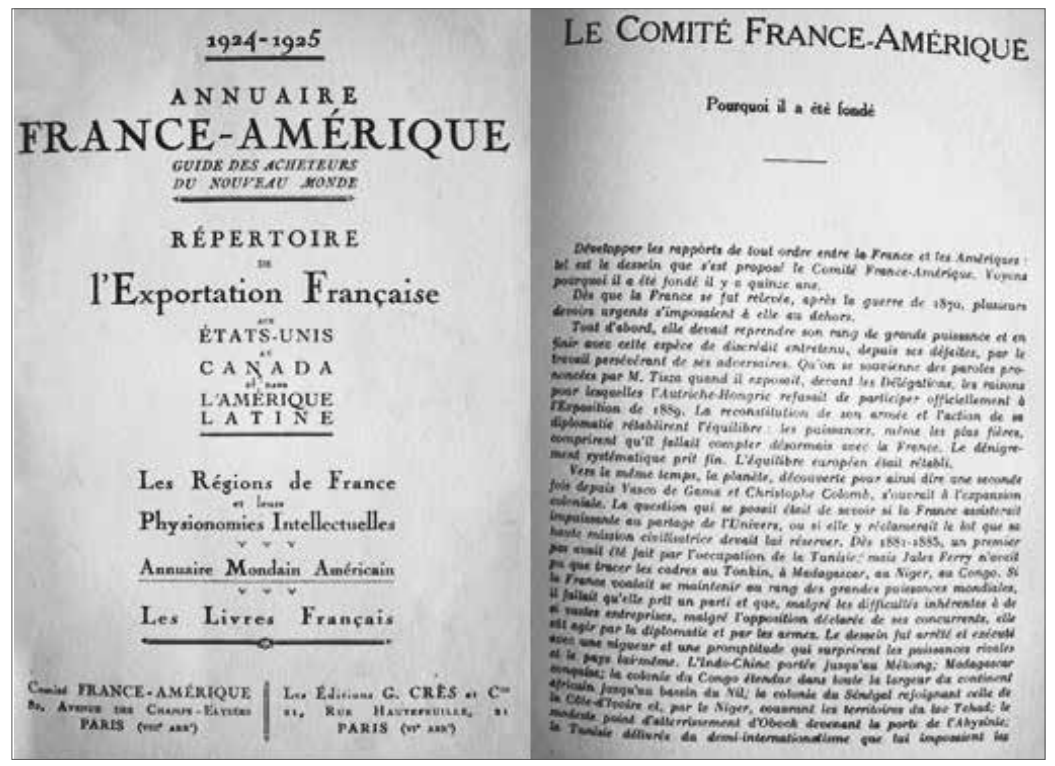

Imagen 16. Portada del Anuario Francia-América 1924-1925 y página inicial del texto de Gabriel Hanotaux (1925, p. 211). Fuente: Biblioteca Nacional de Colombia 
Existen rastros de sus publicaciones hasta 1961, en las cuales el Comité Francia-América impulsó la creación de una colección de publicaciones dedicada a difundir "la historia de las naciones americanas", promovió la fundación de comités correspondientes en América y originó una estratégica organización conocida como Liga Francesa de Propaganda. La colección de textos era el resultado de la Biblioteca del Comité, en la cual se encontraban algunos libros como: La France et la guerre de l'indépendance américaine (1778-1783), escrito por Joachim Merlant; Histoire de la Colombie et du Venezuela, de J. Humbert; Histoire de la Bolivie, de Alcides Arguedas; Historie du Paraguay, cuyo autor fue Cecilio Baez; Historie de l'Uruguay, por Hugo D. Barbagelata; Histoire de l'Équateur, de Cristóbal Gangotena; Histoire de la Repúblique Argentine, de Julia Noé; e Histoire du Chili, por Leonardo Pena (Hanotaux, 1925).

Los comités correspondientes fueron la muestra de una alianza exitosa entre los "fieles amigos de Francia en América" y el denodado esfuerzo que llevaban a cabo los diplomáticos franceses en los diversos consulados al otro lado del Atlántico. En América del Norte, decía el informe, funcionaban oficinas en Montreal, Quebec, Nueva York, Nueva Orleans, Los Ángeles, San Diego, Seattle, Salt Lake City y San Francisco. En América Latina, había unos comités en funcionamiento en Río de Janeiro, Sao Paulo, Montevideo, Santiago de Chile, La Habana, La Paz y San José de Costa Rica; mientras que en Buenos Aires, México, Lima, Bogotá y Quito se encontraban en vía de formación otros grupos de asociados para "atraer a Francia estudiantes y viajeros de las dos Américas y apoyar toda obra o toda acción que pueda dar a conocer América en Francia o Francia en América" (Comité France-Amérique, 1919, p. 218).

Por último, el esfuerzo francés para seguir recuperando la parte del universo que "le correspondía", de acuerdo con lo declarado por Gabriel Hanotaux (1925), se complementó con el establecimiento de la Liga Francesa de Propaganda. Esta organización tenía por objetivo "la defensa de los intereses franceses en América" (Comité France-Amérique, 1925, p. 218), y su característica principal consistía en reunir y asociar establecimientos -no personas- como "sociedades comerciales, industriales y financieras, universidades 
y grandes escuelas, grupos artísticos y turísticos que se interesaron directamente en las relaciones entre nuestro país y las naciones del Nuevo Mundo" (Comité France-Amérique, 1925, p. 218). Para ello, se crearon cuatro comisiones especializadas en educación, bellas artes, industria y comercio, y turismo. Francia ofrecía, así, relatos, historias, acciones administrativas y, con ello, consolidaba su imaginario de "civilización francesa".

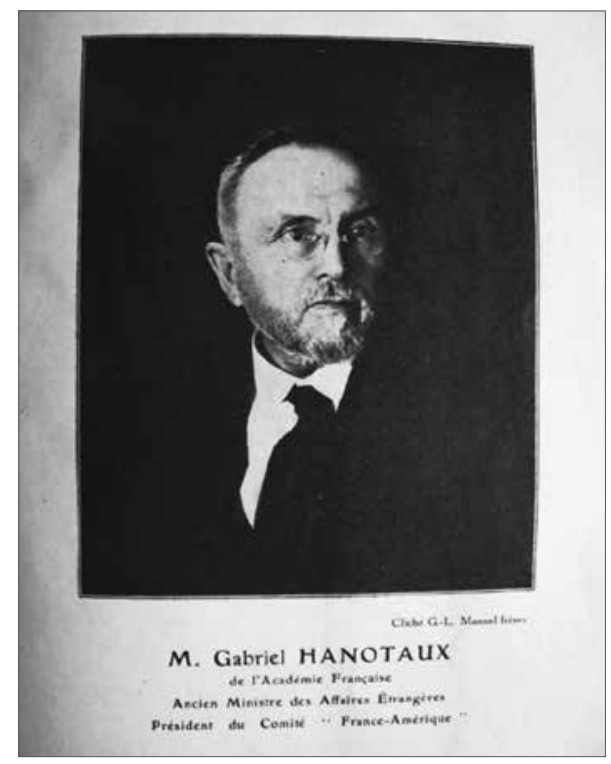

Imagen 17. Retrato de Gabriel Hanotaux, presidente del Comité Francia-América. Fuente: Comité France-Amérique (1925)

\section{Conclusiones}

En primer lugar, desde la perspectiva de las representaciones sociales, políticas y culturales de las independencias hispanoamericanas, las preocupaciones investigativas están orientadas a lo que se dice que pasó y menos a lo que en realidad pasó. En el ámbito de las lecturas francesas de las independencias aquí pensadas, la compleja y rica trama de los procesos parecería, según los autores franceses, fundirse en una relación de causalidad entre los procesos 
de cambios socioculturales, económicos y políticos en Francia, y los que ocurrieron en los territorios hispánicos de dominación colonial.

En segundo lugar, es importante afirmar que la noción "influencia” instituye un lugar común, canónico y predeterminado por las lecturas francesas del siglo XIX sobre las independencias hispanoamericanas. Además, consolida una ecuación política y cultural en la conciencia colectiva e interpretativa de las historias modernas. La reiteración de la categoría influencia para pensar las relaciones decimonónicas entre América y Francia subraya la originalidad, autenticidad y fundamento de las ideas ilustradas, así como de la Revolución Francesa; en cambio, las revoluciones hispanoamericanas representarían una de sus consecuencias más o menos distorsionada a este lado del Atlántico, y un efecto explicable desde París.

La revisión de algunas importantes fuentes bibliográficas internacionales sobre la Revolución Francesa permite identificar, en tercer lugar, una elocuente y eficaz estrategia narrativa que ha logrado, con su tratamiento y sus miradas, hacer que ella, por sí misma, se convierta en el modelo o paradigma de explicación de las luchas políticas y sociales en las sociedades hispanoamericanas. Los códigos de interpretación dominantes han hecho de la esta revolución, la Revolución por antonomasia. En ese sentido, el lenguaje hermenéutico de lo que se dice que pasó instituyó mitos políticos modernos asociados, directamente, con un movimiento exitoso, igualitario, libertario y fraterno.

En cuarto lugar, se puede afirmar que la creación de nuevos órdenes políticos modernos es un patrimonio histórico mundial que contó con la participación de hombres ilustrados que compartieron, a ambos lados del Atlántico y en diferentes partes del mundo, imágenes mentales sobre el poder público, imaginarios políticos de cómo conducir una revolución capaz de incluir nuevos derechos individuales, y sujetos cosmopolitas en sus formas de hacer, sentir y pensar lo político, más allá de las rígidas e imaginativas pertenencias nacionales. En ese contexto planetario de las dinámicas de modernización política, "lo francés" debe ser pensado como una parte de los procesos de mundialización de la modernidad, y no como la impronta modelo de los procesos de creación y transformación de los órdenes 
políticos republicanos. En tal sentido, los intelectuales franceses, y lo que podría llamarse "francés", hacen parte de una comunidad intercontinental de interpretación política que piensa y repiensa las historias del mundo, revisando conceptos, contextos y actores de lo que han sido los procesos políticos independentistas modernos.

Por último, este acercamiento al grupo de autores franceses y afrancesados, señalados a lo largo del texto, permite no solamente una nueva mirada a las representaciones sociales, políticas y culturales de las independencias hispanoamericanas, sino también una revisión de los marcos mentales y conceptuales, de su cultura política, desde donde pensaban aquellos autores. Dicho examen social y cultural de la producción intelectual presentada permite, a su vez, repensar el lugar de Europa en las historias del modelo de modernidad que se ha ido tejiendo a lo largo de los últimos quinientos años. Además, posibilita una mirada crítica a las historias nacionales (Francia, España, Alemania, etc.) o continentales (Europa, América, Latinoamérica, etc.), de tal forma que se puedan comprender mejor las complejas redes multidireccionales en medio de las cuales se han llevado a cabo los procesos de modernización; es decir, los resultados de las luchas entre valores modernos y antimodernos $\mathbf{I}$

\section{Referencias}

Acta General de la Conferencia de Berlín (26 de febrero de 1885). Recuperado de https://www. dipublico.org/3666/acta-general-de-la-conferencia-de-berlin-26-de-febrero-de-1885/

Anderson, B. (1993). Comunidades imaginadas. Reflexiones sobre el origen y la difusión del nacionalismo. México: FCE.

Aubert, G. (1901). Les nouvelles Amériques, notes sociales et économiques, États-Unis, Mexique, Cuba, Colombie, Guatemala, etc. Paris: Ernest Flammarion.

Bianconi, F. y Broc, E. (1887). Colombie et Équateur, Collection des études générales géographiques, Cartes comerciales. Paris: Imprimerie et Librairie Centrales des Chemins de Fer.

Bonaparte Wyse, L. N. (1886). Le Canal de Panamá: L'isthme Américain explorations, comparaison des tracés étudiés, négociations, état des travaux. Ouvrage contenant: une grande carte de L'isthme Colombien, un plan panoramique du Canal de Panamá supposé achevé, un tableau synoptique des divers projets et 90 gravures sur bois. Paris: Librairie Hachette. 
Buenaventura, M. M. (1946). Influencia de Francia en la Independencia de Colombia y después en su economía. En Servicio Francés de Información, Afinidades Francia y América del Sur (pp. 89-93). Montevideo: Impresora Uruguaya.

Calderón, M. T. y Thibaud, C. (2010). La majestad de los pueblos en la Nueva Granada y Venezuela, 1780-1832. Bogotá: Universidad Externado de Colombia/Taurus.

Chevalier, F. (1999). América Latina. De la independencia a nuestros días. México: FCE.

Chicangana-Bayona, Y. A. y Ortega Martínez, F. A. (Eds.), (2011). 200 años de independencia. Las culturas políticas y sus legados. Medellín: Universidad Nacional de Colombia.

Comité France-Amérique (1917). L'Euvre du Comité France-Amérique de 1909 à 1918, Bibliothèque du Comité "France - Amérique". Paris: Imprimerie Levé.

Comité France-Amérique (enero, 1920). France Amérique, revue mensuelle. Recuperado de https:/gallica.bnf.fr/ark:/12148/bpt6k2990548/f5.image

Comité France-Amérique (1925). Annuaire France-Amérique: guide des acheteurs du nouveau monde. Répertoire de l'exportation française aux Etats-Unis au Canada et dans l'Amérique Latine. Paris: Les Éditions G. Crès.

De Gouges, O. (1791). Déclaration des droits de la femme et de la citoyenne. Paris: s. e.

De Plaza, J. A. (1850). Compendio de la historia de la Nueva Granada, desde antes de su descubrimiento, hasta el 17 de noviembre de 1831. Bogotá: Imprenta del Neogranadino por León Echeverría.

Deberle, A. (1876). Histoire de l'Amérique du Sud, depuis la conquête jusqu'à nos jours. Paris: Librairie Germer-Baillière et Cia.

Escobar Villegas, J. C. y Maya Salazar, A. L. (2010). Batallas líricas. Los juegos florales y las independencias en Iberoamérica. En E. Domínguez Gómez (dir.), Todos somos historia (Vol. 3) (pp. 47-57). Medellín: Canal Universitario de Antioquia.

Escobar Villegas, J. C. y Maya Salazar, A. L. (2011). Ilustrados y republicanos, el caso de "La ruta de Nápoles" a Nueva Granada. Medellín: EAFIT.

Filippi, A. (Dir.), (1995). Bolivar y Europa en las crónicas, el pensamiento político y la historiografía. Caracas: Ediciones de la Presidencia de la República.

Godineau, D. (1995). La mujer. En M. Vovelle (comp.), El hombre de la ilustración (pp. 395 428). Madrid: Alianza.

Groot, J. M. (1853). Los misioneros de la herejía, o, Defensa de los dogmas católicos, en contestación al índice publicado en Bogotá por Unos protestantes. Bogotá: Imp. de F. Torres Amaya.

Groot, J. M. (17 de noviembre de 1857). Jesucristo o Bentham. El Catolicismo, 2(292), 366-367. 
Groot, J. M. (1869a). Defensa de la pastoral de 19 de agosto sobre la ley de celibato eclesiástico, o, Impugnación de las reflexiones del señor Florentino Vezga sobre la misma pastoral. Bogotá: Imprenta Metropolitana.

Groot, J. M. (1869b). Refutación analítica del libro de Mr. Ernesto Renan titulado "Vida de Jesús". París: Librería Europea de Dramard Baudry.

Groot, J. M. (1869c). Historia eclesiástica y civil de Nueva Granada, escrita sobre documentos auténticos, (Tomo I). Bogotá: Imprenta a cargo de Foción Mantilla.

Groot, J. M. (1872). "De la instrucción primaria", artículos publicados en La Claridad. Bogotá: Imprenta de El Tradicionista.

Groot, J. M. (1894). Dios y patria: artículos escogidos. Bogotá: Casa Editorial de Medardo Rivas.

Gruzinski, S. (2018). ¿Para qué sirve la historia? Madrid: Alianza Editorial.

Guérin, P. (Dir.), (1895). Dictionnaire des dictionnaires: encyclopédie universelle des lettres, des sciences et des arts (Tomo II). Paris: Librairie des imprimeries réunis.

Guerra, F.X. (2001). Modernidad e independencias. Ensayos sobre las revoluciones hispánicas. México: FCE.

Hanotaux, G. (1925). Le Comité France-Amérique. Pourquoi il a été fondé. En Comité France-Amérique, Annuaire France-Amérique: guide des acheteurs du nouveau monde. Répertoire de l'exportation française aux Etats-Unis au Canada et dans l'Amérique Latine (pp. 211-213). Paris: Les Éditions G. Crès.

Lucena Giraldo, M. (2010). Naciones rebeldes. Las revoluciones de independencia latinoamericanas. Madrid: Taurus.

Maya, R. (1954). Francia en la literatura colombiana. En Estampas de ayer y retratos de hoy (pp. 435-453). Bogotá: Ministerio de Educación Nacional/Ediciones de la Revista Bolívar.

Mirkine-Guetzévitch, B. (1936). Préface. En P. Sagnac, B. Mirkine-Guetzévitch y A. Pierre, Cahiers de la Révolution Française (pp. 1-7). Paris: Recueil Sirey.

Mommsen, W. J. (1969). La época del imperialismo. Europa 1885-1918. México: Siglo XxI.

Ortega, F. A. y Chicangana-Bayona, Y. A. (Eds.), (2011). Del dicho al hecho. 200 años de independencia y ciudadanía en Colombia. Bogotá: Museo Nacional de Colombia.

Parlamento Británico (13 de febrero de 1689). La declaración de derechos (The Bill of Rights). Recuperado de http://bibliohistorico.juridicas.unam.mx/libros/6/2698/20.pdf

Quijano Otero, J. M. (1883). Compendio de Historia Patria. Para el uso de las escuelas primarias (2.. ed.). Bogotá: Imprenta de Medardo Rivas. 
Real Academia Española (2014). Diccionario de la lengua española (23.ㄹ ed.). Madrid: Espasa Calpe.

Restrepo, J. M. (1827). Historia de la revolución de la República de Colombia. París: Librería Americana.

Restrepo, J. M. (2009a). Historia de la revolución de la República de Colombia en la América Meridional (5. ${ }^{a}$ ed.) (Tomo I). Medellín: Universidad de Antioquia.

Restrepo, J. M. (2009b). Historia de la revolución de la República de Colombia en la América Meridional (5. a ed.) (Tomo II). Medellín: Universidad de Antioquia.

Restrepo Tirado, E. (1929). Beneficios de la conquista española sobre los primitivos habitantes de Colombia. Conferencia pronunciada en la Real Asociación de maestros de primera enseñanza. Sevilla: Imprenta S. Peralto.

Sagnac, P., Mirkine-Guetzévitch, B. y Pierre, A. (1936). Cahiers de la Révolution Française. Paris: Recueil Sirey.

Sala-Molins, L. (1987). Le Code noir ou le calvaire de Canaan. París: Presses universitaires de France.

Samper, J. M. (1853). Apuntamientos para la historia política i social de la Nueva Granada, desde 1810, i especialmente de la administración del 7 de marzo, dedicado a la juventud liberal. Bogotá: Imprenta del Neo-Granadino.

Servicio Francés de Información (1946). Afinidades Francia y América del Sur. Montevideo: Impresora Uruguaya.

Torres Caicedo, J. M. (1882). Echos de L'Union Latinoaméricaine. Paris: Imprimerie Nouvelle. 